\title{
THE POEM KNOWN AS
}

\section{BEOWULF}

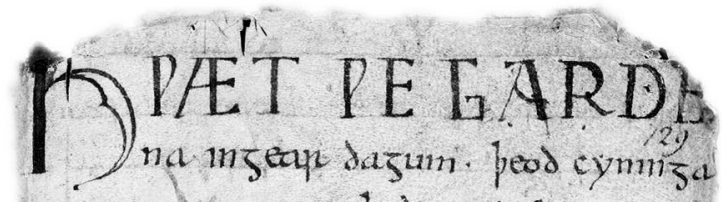

prym sf prumon huda apelmsaf elle fremedon. ofe feyld foepms feeaper preatum monezü maspum meodo pelk of ceali sfode eopl syblan cepefe pezte fea forafe funden he puef popre seba peox undep polenum peopis myndan pah of phim ashpyle para yomb fiezendya oper inron pade hypan foolde sombar

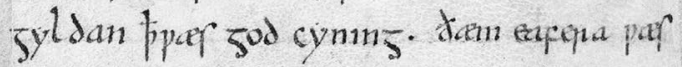
af equ cenned stons in seapdum pone 5od pende folce zoppoppe fypan diappe on jere phe apdunģon aldonative. lange hpile hm puef lip frea puldsicf pealides

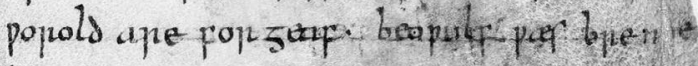

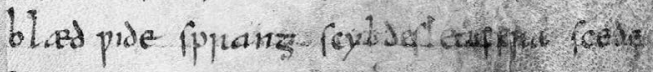

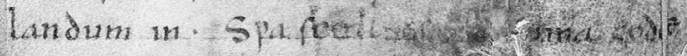

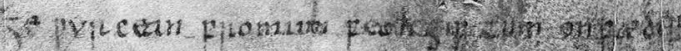


Heyla! ${ }^{1}$ We have a story about the Spear-Danes, from the old days when they were big and their kings showed their strength. There was one king, Shield Schefing, who stole many mead-benches from other tribes and terrified their leaders. At first, he was found weak and wandering, but was taken in and then grew under the comfort of the skies. He consumed honors until each of the other surrounding tribes over the whale's road were forced to obey him and pay tribute. They say, that was a good king.

After all this (when he was old), Shield had a son-a young one in the courtyard-who had been sent by God as a comfort to the people because He had seen how they were distressed, left without a strong leader for a long while.

The Lord of life, ${ }^{2}$

ruler of glory, gifted worldly honour:

Beowulf was famed with widespread renown, son of Scyld, in the northern lands.

So should a young man do good things with costly gifts in his father's care, so that in old age loyal companions remain with him afterwards; when war comes they will support their prince. Through glorious deeds a man shall prosper among peoples everywhere.

Scyld then set off at his due time, the mighty lord went into the Lord's keeping. His beloved companions carried him then to the water's edge, as he himself had instructed when he still governed, that much-loved Scylding friend, their ${ }^{3}$ beloved land-prince held power a long time.

There in the port a ring-prowed ship stood anchored, icy and eager, a nobleman's vessel.

They laid down their dear king, giver of rings, in the bosom of the ship, mighty by the mainmast. There were many treasures from faraway lands, such precious things loaded there. I have never heard of a finer ship fitted with the weapons and armor of war, swords and harnesses. In its embrace lay a multitude of treasures, which were to go with him far off, into the dominion of the sea.

I Tarren Andrews and the Flathead Indian Reservation (1-16a)

2 Elaine Treharne (ll. 16b-30)

3 Jill M. Fitzgerald (ll. 31-45) 
READER'S NOTES AND TRANSLATION 
No fewer gifts were provided for him there, the very wealth of a nation, than what was once done by those who, at his birth, set him adrift,

alone ${ }^{4}$ over the waves as a child.

Then they set for him a golden banner

high over his head, let the water carry him,

gave him to the powers of the sea. In them there was a sad spirit,

a mournful mind. Men did not know,

to tell the truth, hall counselors,

heroes under the heavens, who accepted that load.

\section{I}

Then was in the stronghold Beow of the Scyldings

a beloved king of the people for a long time,

famous among the folk. His father had gone elsewhere,

that honored one had left the earth. Until to Beow once more was born

high Healfdene, who held while he lived,

old and battle-fierce, the glorious Scyldings.

From him four children all told

arose into the world, from the leader of the host,

Heorogar, ${ }^{5}$ and Hrothgar, and Halga the Good.

That woman, I heard, was the noble one's queen,

the beloved bedfellow of the Battle-Scylfing.

Then Hrothgar was granted success in war, glory in battle, so that his dear kinsmen

served him eagerly, until the young warriors

grew to be a mighty troop. He had the idea

that he should bid men to build

a house, a great mead-hall, which

the children of men would hear of forever.

And there within he would share everything, with young and old, such as God gave him, except for the common land and lives of men.

Far and wide then I heard the work was declared

to many peoples throughout this middle earth,

4 Angela B. Fulk (ll. 46-60)

5 Shu-han Luo (ll. 61-75) 
READER'S NOTES AND TRANSLATION 
$\mathrm{To}^{6}$ adorn the place of the nation. It happened to him in time,

Quickly among men, that it was all ready,

The largest of hall-buildings. He gave it the name "Heort,"

He who had power of his word far and wide.

He did not neglect his vow, distributed rings,

Treasure at the feast. The hall towered,

High and wide-gabled. It awaited the flames of battle,

The hated fire. It was not to be much longer,

Until the sword-hatred, swearing with oaths,

After murderous malice, would awaken.

Then the powerful spirit miserably

Endured the time, he who lived in the shadows,

When he each day heard merriment

Loud in the hall. There was the music of the harp,

The clear song of the scop. He spoke, who knew how

To narrate from afar the origin of men,

Said that the Almighty created the earth,

The bright beauteous land, as the water surrounds it,

Established victorious the sun and moon,

The luminaries as light for land-dwellers,

And adorned the fields of the earth

With branches and leaves, He also created life

For each of the kindreds that move about alive.

So those courtiers lived happily,

Blessedly, until one began

To carry out crimes, an enemy in hell.

That grim spirit was called Grendel,

The infamous border-walker, who ruled the moors,

The fens and strongholds. The land of the race of monsters

That miserable man lived in for a time,

after ${ }^{7}$ the Creator had condemned him

with Cain's kin. That killing He punished,

the everlasting Lord, the slaying of Abel.

There was no relish in that feud, for He banished him far away,

the Maker for that sin, away from mankind.

From him awoke each kind of onerous offspring:

enemies and elves and evil spirits

and likewise giants, who wrestled with God

time and time again; He repaid them a reward for that. 
READER'S NOTES AND TRANSLATION 
He advanced then as soon as night came, sought the high house, and how the Ring Danes had occupied it after their beer-banquet. He found within there a band of princes sleeping after the feast. Sorrow they did not knowthe misfortune of men. The wretched wight, grim $^{8}$ and greedy, was ready at once,

fierce and furious, and from their rest he seized thirty thegns. From there he left, boasting of booty, to return home, sated by slaughter, to find his abode. It was at dawn, with daybreak, that Grendel's war-cunning became known to men. Then after feasting woe arose, a great cry in the morning. The renowned leader, the good prince of old, sat mournfully; the mighty one suffered, bore sorrow for his thegns, once they witnessed the track of that loathed one, of that cursed spirit. That strife was too strong, loathed and lengthy. It was not much later, only after a night, he acted again, perpetrated ${ }^{9}$ greater murder-slaughter, and mourned not for it, acts of feuding and crime; he was too fixated on them. Then the man was easy to find who would elsewhere, further away, seek his resting place, a bed among the outer buildings, when it was shown to him, truly told with a clear sign:

the hatred of the hall-thane; he kept further away and more securely afterwards, whoever had escaped the fiend. So he ruled and strove against justice, one against all, until it stood abandoned, that best of halls. The time was long: For the space of twelve winters he endured anguish, the friend of the Scyldings, every kind of woe, endless sorrows. Therefore, it became visible to the children of mankind, known and revealed 
READER'S NOTES AND TRANSLATION 
sadly ${ }^{10}$ in stories, that Grendel struggled

for a long time with Hrothgar, and carried forth his hate-violence, his sins, and his enmity, for many half-years, a perpetual strife. He wanted no friendship with any men of the Danish host, and wished neither to cease his deadly evil, nor settle for a fee; nor did the wise advisers there have reason to expect brilliant compensation from the hands of the slayer. The hideous opponent, the dark death-shadow, pursued both the aged and the young; he lay in wait and ambushed them, and in perpetual night held the misty moors. Men do not know which way hell-demons glide in their goings. Thus, the enemy of mankind, hideous and solitary, often carried out his many crimes, harsh ${ }^{11}$ injuries. He dwelled in Heorot, the richly ornamented hall in dark nights. Not at all could he touch the gift-seat, the precious thing because of God, nor did he know his purpose. That was great misery for the lord of the Scyldings, the mind's griefs. Often many a mighty man sat in consultation; they heeded the advice, what for strong-minded ones would be best to do against the perilous horror. Sometimes they vowed at heathen temples reverence to idols, urged with words that the soul-killer would grant them aid against the people's threat. Such was their custom, hope of the heathens. They remembered hell in their minds, they did not know the Creator the ${ }^{12}$ Judge of deeds, nor did they know the Lord God.

Nor indeed did they understand how to praise Heaven's Protector, the Ruler of Glory. Woe shall befall the one who must, because of evil affliction, thrust their soul into the fire's embraces, unable to hope for comfort or any change. Well shall it be for the one who is able, after their death-day, to go to the Lord and seek the protection of the Father's embraces.

10 Alexander D’Alisera (1l. 151-165)

I I Janine van Drünen (ll. 166-180)

12 Maggie Scott (ll. 181-195) 
READER'S NOTES AND TRANSLATION 
III

Thus, on the sorrow of the age, the son of Healfdene brooded ceaselessly. The wise warrior was unable to set misery aside. The oppression was too severe; grievous and relentless, it had befallen the people; cruel, violent torment, the greatest of night terrors. News was heard in the homeland of Hygelac's warrior, a man respected among the Geats, of Grendel's actions. $\mathrm{He}^{13}$ was mankind's strongest of might

in those days of this life, noble and great. He asked to equip a good ship. He said he would seek the war king over the swan road, famous king, since he was in need of men. Not at all did the wise noblemen blame him for the adventure, though he was dear to them, they urged the valiant one. They studied omens. The good man had from the Geats chosen warriors, those the bravest he might find. One of the fifteen went to the ship, the man led the way, the sea-skilled man, to the shore. $\mathrm{A}^{14}$ span of time passed. The ship was on the waves, the ${ }^{15}$ boat beneath the bluff. Noble ones, equipped, ascended the ship. Currents whirled, water against the sand. Warriors carried into the ship's hold shimmering treasures, emblazoned battle-gear. The men shoved off, men on their willed-for journey, in a well-bound boat. Then they left, over the whale-home, propelled by the windthe frothy-necked boat looked most like a birdeven after the expected time of the following day had elapsed, the stem-twisted ship had travelled, so that those sailors saw land: the gleaming sea-cliff, high promontory, expansive sea-ness. Then the sea voyage was over, the ocean ended whence, quickly, the people of the Weder-Geats stepped onto the strand;

13 Barbara Lee Bolt (1l. 196-209)

I4 Jean Abbott (fragments and transitions: ll. 210, 510, 795, 840b, 1201-1202, 1471-1474, 1665b, 1771, 2310a, 2581a, 2656-2657a, 2688, 2821, and 3121)

I5 Rebecca Shores (1l. 211-225) 
READER'S NOTES AND TRANSLATION 
the ${ }^{16}$ sea-wood was moored, the mail-shirts resounding, the battle-garb. They gave thanks to God that the wave-ways were easy for them.

Then the ward of the Scyldings saw them from the wall, he who must keep the ocean-cliffs, must bear bright spears over the deck, ready in his war-gear. Curiosity plagued him in his mind-thoughts who these men were. Then he departed riding his horse to the shore, the thane of Hrothgar, brandishing mightily the strong wood in his hands, asking in formal terms, "Who are you all, armor-having warriors guarded in your corslets, who have thus come leading your steep ship over the watery lanes, to here across the seas?" He amid his select troop was at ${ }^{17}$ the farthest point, held watch by the sea, so that no enemy with a sea-invading army might do harm in the land of the Danes. "Shieldbearers have not more openly dared to come, nor did you know that leave would be readily granted from those accomplished in battle, permission from kinsmen. I never saw a greater man in the world than is one of you, a fighter in war-gear; he is not merely a hallretainer decked out with weapons unless his looks betray him, his unique appearance. Now I shall know your lineage, rather than you go farther from here as spies into the land of the Danes. Now you travelers from afar, you sea-journeyers, hear this ${ }^{18}$ simple thought: that it is advisable to say quickly from where you came."

\section{IV}

That noblest of men, the leader of the company, answered him, unlocking his word-hoard: "We are from the nation of the Geatish people, and Hygelac's hearth-companions. My father, a great warrior, was well known among the people. He was called Ecgtheow. He saw many winters before he departed on his journey from this world. He was well-regarded by the wise throughout the whole wide world. We come in good faith to your lord, the son of Healfdene, the protector of your people. Let your counsel be true! We have a great message to declare to him,

16 Aaron K. Hostetter (1l. 226-240)

17 Lesley E. Jacobs (11. 241-255)

18 Mary Leech (1l. 256-270) 
READER'S NOTES AND TRANSLATION 
to ${ }^{19}$ the lord of the Danes. Nor shall there be

anything secret, I expect: you know, if it is

truly as we have heard tell,

that an enemy of some sort among the Scyldings,

a secret persecutor in the dark nights,

manifests terror and awful affliction,

humiliation and slaughter. I can give Hrothgar

this counsel from my generous mind,

how he, wise and good, may overcome the enemy-

if a reversal of fortune should ever come to him,

a remedy of these afflictions come again,

and the seethings of his sorrow become cooler,

or always afterward endure a time of tribulation,

a great distress while the best of houses

remains in its high place."

The ${ }^{20}$ guard spoke from where he sat on horseback,

the fearless officer. "A keen shield-warrior,

he who considers well, must know

the distinction between both words and deeds.

I hear that this host is friendly

to the king of the Scyldings. Go forth bearing

your weapons and gear; I will guide you.

Likewise I will command my young followers

to guard your ship with honor against all enemies,

this newly-tarred vessel on the sand,

until the twist-prowed wood carries

back over the ocean currents to the Weder borders

every beloved man among these doing good,

who is fated to survive the battle-rush whole."

They $^{21}$ went to leave then. The ship stayed in place,

rested in the tideland, the wide-bosomed vessel

secured at anchor. Boar effigies,

gold-touched, gleamed above cheekguards-

a decorated, fire-hard thing to keep watch over life.

War-hearted ones clattered, fell in together,

the men hurried on till they caught sight of it

fully timbered, fitted out richly, trimmed with gold:

that hall, the most famous to land-dwellers

under the heavens, in which the mighty one abode.

19 Jacob Hobson (1l. 271-285)

20 Elizabeth A. Williamsen (ll. 286-300)

2I Britt Mize (ll. 301-315) 
READER'S NOTES AND TRANSLATION 
Its brightness shone on many lands.

The fierce fighter pointed them to the splendid

home of the proud so they could march

right to it. One among warriors,

he turned his horse, spoke a word behind him:

"It ${ }^{22}$ is time for me to depart. May the all-ruling Father keep you safe on your journeys through his kindness. I will go to the sea to keep watch against a hostile troop."

The street was stone-paved; the path guided the warriors together. The hard, hand-linked battle-byrnie shone, the bright iron-ring of the armor resounded, when they first set out for the hall in their awe-inspiring armor. The sea-weary men set down their wide shields, those exceptionally hard rounds, against the wall of the building; they bent down onto the bench - the byrnies, the warriors' war-gear, rang; the spears stood, the gear of the sea-men gathered together, an ash-grove topped with gray; the armed troop was honored ${ }^{23}$ in its weapons. Then the bold warrior asked those combatants about their own warriors:

"Where do you come from bearing gilt shields, grey hauberks, and grim helmets, that band of battle-shafts? I am Hrothgar's herald and attendant. I have never seen a foreign host, so many men, looking more courageous.

I expect that you, because of boldness, not banishment, and for strength of heart, sought Hrothgar."

To him then the valor-brave answered, proud prince of the Weders, pronounced these words, hardy under his helm: "We are Hygelac's

table-mates. Beowulf is my name.

I want to tell Halfdane's son, that peerless prince, my errand, to ${ }^{24}$ your prince, if he will allow us, so that we may greet him, this good man." Wulfgar spoke formally. He was the Wendels' prince, his courage of spirit known to many, at war and in wisdom: "I will ask

22 Jonathan Davis-Secord (1l. 316-330)

23 Peter Buchanan (1l. 331-345)

24 Jill Frederick (ll. 346-360) 
READER'S NOTES AND TRANSLATION 
the Danes' friend, the Scyldings' ruler, the giver of rings, as you have requested, the celebrated prince, about your errand, that you quickly know the answer which that good man thinks to give me." He turned quickly then to where Hrothgar sat, old and very grey, with his troop of noblemen.

The braveheart went so that he stood by the shoulder of the Danes' ruler. He knew the custom of warriors.

Wulfgar spoke properly to his good lord:

"The ${ }^{25}$ Geatish people are led here,

Come from afar over an expanse of sea.

Warriors call the chief one

Beowulf. They are requesting,

My king, that they might

Exchange words with you. Do not refuse them

Your answers, gracious Hrothgar.

In war-equipment, they appear worthy

Of praise from warriors; indeed, the chief

Who lead the warriors hither is powerful."

\section{VI}

Hrothgar, protector of the Scyldings, spoke:

"I knew him as a boy;

His late father was called Ecgtheow;

Hrethel of the Geats gave him his only daughter

As a wife; now his son,

The ${ }^{26}$ brave one, has come here to seek a loyal lord.

From Geatland far, whence seamen sailed

Bearing gifts of thanks come tales of one

Whose hand-grip rivals that of thirty men,

A hero of battle-fame.

$$
\text { Holy }^{27} \text { God }
$$

For our honor has sent him to us,

The West-Danes, as I would hope,

Against Grendel's terror. For the good man's might

And great daring I shall bestow gifts.

Now make haste, call them inside

25 Stephanie Opfer (1l. 361-375)

26 Emrys Holmes, Oshay Columbus, Branden Printup, and Kelsey Waddy (ll. 376-381a)

27 Jasmine Phillips, Kevin Fabery, Arianna Marealle, and Andre Ross (ll. 381b-387) 
READER'S NOTES AND TRANSLATION 
To look upon my band

of kinsmen gathered together.

Tell $^{28}$ them in words that they are welcome

To the people of the Danes."

Wulfgar relayed the word:

"My lord bids me to tell you, the victory-lord, leader of the East-Danes, that he knows of your nobility and that you have sailed across the sea-wellings.

We welcome you here, spirited ones.

"Now ${ }^{29}$ you may come forth in your armor,

Wearing your war-helms, to witness Hrothgar. However, you must leave your battle-shields, Your weapons of wood behind while we discuss the matter." Then the Geatish ruler rose, surrounded by his loyal retinue, A splendid troop of thanes.

\section{Some ${ }^{30}$ bided there}

To keep the battle-gear guarded as the brave one ordered.

Guided by the warrior together they hastened

Under Heorot's roof. [The warrior strode]

Hardy under helm, 'til he stood in the hall.

Beowulf spoke, in his shining byrnie,

His battle-net skillfully smithed:

"Be ${ }^{31}$ thou, Hrothgar, well. I am Hygelac's

kinsman and young retainer. In my youth I have undertaken many glorious things. This thing with Grendel became apparent to me on my native soil.

Seafarers say that this hall stands, the best of halls to every man, idle and useless, since evening's light became hidden under the brightness of heaven.

Then persuaded me, mine people, the best men, the wisest men, lord Hrothgar, that I you seek because they knew the strength of my skill; they themselves had observed, when I came from battle, bloodstained from the enemy, where I bound five together, destroyed a family of giants, and in the waves slew

28 Jaylon Mallory, Tristan Cox, Janea James, and Carrie Moll (1l. 388-393)

29 Sarah Thompson, Katrina Graham, Ashley Lesley, and Jessica Silvis (ll. 394-399a)

30 Lauren Rosenblatt, Brea Walker, Phong Vo, and Lindsey Allen (ll. 399b-405)

3I Martha Valenzuela (1l. 406-420) 
READER'S NOTES AND TRANSLATION 
water-monsters ${ }^{32}$ by night, endured dire distress,

avenged assaults on the Weders. They asked for that woe,

I crushed the hostile ones. And now with Grendel,

with that miserable wretch, I will by myself hold

a meeting with the giant. Now I ask you,

lord of the Bright-Danes, I would ask you,

shelter of the Shieldings, a single favor,

that you not refuse me, refuge of fighting men,

noble friend of the folk, now I have come thus from afar:

that I myself might, with this troop of my earls

and this hard company, cleanse Heorot.

I have also found out that the foe

in his recklessness disregards weapons.

I will therefore forego them, so that Hygelac,

my liege-lord, may be glad of heart,

scorn $^{33}$ that I should bear sword or broad shield,

436

yellow-board to battle, but with my grip

I shall grapple with the fiend and fight for life,

enemy against enemy. Let him trust

in the Lord's judgement, he whom death takes!

I expect that he desires, if he is allowed to have mastery

in that war-hall, to feed fearlessly

on the Geatish people just as he often has done,

the strength of the Hrethmen. Nor will you need

to cover my head, but he will have me,

stained with blood, if death takes me.

He will bear my bloody corpse, think to taste it,

to ruthlessly eat the solitary one,

mark his moor-retreat with blood. You need not for a moment

worry about the disposal of my body.

To ${ }^{34}$ Higelac send, if battle takes me,

My splendid armor, best of battle-shirts,

My breast's defender, Hreðel's gift to me,

The work of Weland. Fate cannot be stopped."

32 Leah Pope Parker (ll. 421-435)

33 M. Breann Leake (ll. 436-450)

34 Amy Smith (1l. 451-465) 
READER'S NOTES AND TRANSLATION 


\section{VII}

Thus Hroðgar, lord of Scyldings, gave reply:

"For fights, dear Beowulf, you sought us out-

For favors came to me. Your father killed

A man; with sword in hand he caused a feud:

With Wilfingas he murdered Heapolaf.

He feared the Weders' vengeance, wrath of kin,

And fled from home, afraid to stay with them.

He, seeking refuge, sought the South-Dane folk,

The honored Scyldings, over rolling waves,

When first I ruled the Danish folk in youth-

A king with power over men and wealth,

$\mathrm{a}^{35}$ rich fortress of warriors. At that time Heorogar was dead, my

elder brother was no longer alive, Healfdene's son. He was better

than I am. Afterwards, I settled the feud with money. I sent old trea-

sures to the Wylfings over the water's crest. He swore oaths to me. It

grieves me in my heart to tell any man what humiliations, what sudden afflictions Grendel has caused in Heorot because of his hateful thoughts. My hall-troop, my band of warriors is lessened. Fate has swept them off into Grendel's terrible power. God may easily hinder the deeds of the wild ravager. Very often warriors vowed over the ale-cup, having drunk beer,

that $^{36}$ they wished to await in the beer-hall

Grendel's attack with the terror of swords.

Then this mead-hall, in the early morning

the princely hall was gore-stained; when daylight shined

all the benches were damp with blood,

a sword-bloody hall. I had fewer faithful ones,

dear warriors, when death took them away.

Sit now at the feast and loosen your thoughts,

your glory gained by swords, as your mind incites you."

Then for the Geat men all together

a bench was cleared in the beer-hall.

There the strong-minded went to sit,

bold in their strength. A thane observed his duty,

he who bore in his hands an ornamented ale-cup,

gave out clear sweet drink. A scop sang at times

clear-voiced ${ }^{37}$ in Heorot. There was joy of heroes,

a host of Danes and Geats, not few in number.

35 Elise Louviot (11. 466-480)

36 Leslie Carpenter (1l. 481-495)

37 M. R. Rambaran-Olm (1l. 496-509) 
READER'S NOTES AND TRANSLATION 


\section{VIII}

Unferth spoke, the son of Ecglaf, who sat at the feet of the lord of the Scyldingshe unbound the war-secret-for him was the journey of Beowulf's, that brave seafarer, a great offence, because he would not allow that any other man on middle-earth ever obtain more glories under heaven than himself. "Are you the Beowulf that fought with Breca on the broad sea, in a swimming contest? Where you, for pride, tempted the waters and for vain-glory in the deep sea risked your lives? Not any manloved or loathed-could dissuade the two of you from that sorrowful ${ }^{38}$ undertaking, when you two rowed out swimming.

There you both enfolded the flowing tide in your arms, measured out the sea-path, wove with your hands, glided over the needling water. The ocean surged with waves in the welling of winter. You two in the water's power labored seven nights. He bested you in swimming, had greater prowess. Then in the morning the tide carried him up to the land of the Heatho-Ræmas; from there, cherished by his people, he sought his dear homeland, the land of the Brondings, the fair stronghold, where he had folk, fortress, and rings. The son of Beanstan, truly stood by his vow against you. So, I expect poor results from you, although at every opportunity you have been strong in the storms of war, In $^{39}$ grim warfare, if you dare await Nearby for Grendel for a night's length."

Beowulf spoke, Ecgtheow's son:

"You hear me out, Unferth, my friend, You are beer drunk, speaking about Breca And talking tall about his journey. The truth, I claim, is that my seastrength was greater, and nobody else endured more wave hardships. We said that and boasted, boyish as we wereBoth such youthful braggarts in those daysSaid we would swim the sea and we did. 
READER'S NOTES AND TRANSLATION 
Nakedsworded, we entered the saltwaves, In hand our weapons: whalesbane; We intended to fend off the fearsome fish. We swam and not one span from me Could ${ }^{40}$ he float, far on flood-waves,

Swift on sea, nor would I go from him.

So, at one on the sea were we,

For five nights, til the flood drove us apart, Welling waters, coldest of weathers, Night drawing nigh, and the north wind, Hurling harshly against us. High were the waves! The fury of the ocean-fish was roused: There my mail-shirt maintained me, Hard-locked against foes; helped me, My braided battle-plate lying on my breast, Gilded with gold. It bore me down to depths, The foul foe-fiend, held me fast, Grim its grip. Yet was it given to me To reach that wretch with my razor-edged battle-blade. ${ }^{41}$ The war-rush consumed the mighty sea-beast through my hand."

\section{IX}

"So the hateful creatures continually pressed me sorely. I served them with my good sword, as they deserved. They had no joy at that feast, wicked destroyers, those that devoured me sat at a feast near the sea-floor but in the morning, wounded by blades they lay dead by the wave-swept shore by swords put to death, that never afterwards round the deep-ford, the sea-faring were hindered in their course. Easterly, light came, bright beacon of God, the sea's surface stilled, so $^{42}$ that I saw the wind-swept sea-walls

of the headlands. Luck often saves

the unweaved warrior, if his courage keeps.

40 Siân Echard (ll. 541-555)

4I Brian Christopher Hardison (ll. 556-569)

42 Justin Briley (ll. 570-582a) 
READER'S NOTES AND TRANSLATION 
And I myself slew nine sea-serpents with my sword. Not one night under God's sky have I heard of a fiercer fight, nor on the waves, of a more beleaguered warrior. But I escaped their coils, intact, but world-worn. The sea bore me away, current-bound, to the Finnish lands, on surging waves. And never have I heard a thing about any brawls, or battles, or broken blades of yours.

$$
\text { Breca }^{43} \text { never yet }
$$

at battle-play, nor either of you two, accomplished so bold a deed with bright swords. I do not boast of this, though you became a killer to your brothers, your close kinsmen. Because of that you shall suffer torment in hell, though your mind may be good. I tell you truly, son of Ecglaf, that Grendel never would have committed so many horrors, that terrible fierce assailant, to your lord, humiliations in Heorot, if your heart, your spirit, were as battle-grim as you yourself consider.

But he has found that he does not need greatly to fear the hostility, the terrible sword-strength, of your people, of the Victory-Scyldings.

He takes an enforced toll, is merciful to none of the people of the Danes, but he takes delight, kills and dispatches, does not expect strife from the Spear-Danes. But soon now I shall show ${ }^{44}$ him the strength and courage of the Geats, summoning him to battle. Afterwards, any who will may go to mead bravely when morning light from the South shines bright over the children of men on the following day, the sun clothed in radiance." Then he was joyful the giver of treasure grey-haired and famous in war; the Bright-Danes' leader believed in this help; listening to Beowulf the people's shepherd heard steadfast resolution. There was heroes' laughter, the sweet din resounded, and words were winsome. Wealtheow went forth,

43 Yvette Kisor (ll. 582b-600)

44 Melissa Ridley Elmes (1l. 601-614) 
READER'S NOTES AND TRANSLATION 
Hrothgar's queen mindful of custom, gold-adorned, greeting the men in the hall, and that noble wife gave a cup first ${ }^{45}$ to the Lord of the East Danes, bade him bliss at the beer-drinking, beloved of the folk. He eagerly enjoyed feast and mead-cup, victorious lord. Then she walked around, the woman of the Helmings, to the old and the young warriors, each at his bench, holding the cup, the ring-adorned queen coming finally to Beowulf.

Worthy of mind the mead-bearer greeted the dear Geat, thanking God with wise words for the fact that she'd got her wish, that such an earl had emerged to offer relief from horrors. He took the full cup from Wealtheow and spoke then, battle-eager Beowulf, son of Ecgtheow, spoke: " ${ }^{46}$ had it in mind when I mounted the swell, sat in the sea-boat with soldiers in order, that-no matter what-the will I'd do of all you people, else perish in slaughter in the fiend's tight grasp. I'll follow through with a hero's valor, else here in the mead-hall the end of me I'll meet for sure."

These words the woman well did impress, this boast from the Geat. Gold-adorned she went, lady of the people, by her lord to sit. Then again, as erstwhile, inside the hall noble speech reigned-the rabble lightheartedthe tumult of winners, until in the end the son of Healfdene sought to retire for night's repose. He knew that monster planned ${ }^{47}$ an attack against that high hall.

After they could see the sun's light, until darkening night, shapes from the cover of shadow, came crawling over everything, dusky under the clouds. The troop all arose.

45 David Hadbawnik (ll. 615-630)

46 Matthew Boutilier (ll. 631-645)

47 Richard Carter Fahey (ll. 646-660) 
READER'S NOTES AND TRANSLATION 
Then, one warrior greeted the other warrior, Hroðgar to Beowulf, hailed him with fortune, granted command of the wine-house and spoke these words:

"Never, since I could raise hand and shield, have I before entrusted the glorious hall of the Danes, to any man except to you now.

Keep now and protect the best of houses, remember fame, demonstrate mighty courage, watch against wrath. There will be no dearth of desire for you if you survive that courageous work... alive."

Then ${ }^{48}$ Hrothgar departed with his troop of warriors, the protector of the Scyldings, out from the hall; the war-chief wished to seek Wealhtheow, the queen in bed. The King of Glory, so men learned, had appointed a hall-guard against Grendel; he held a special service to the lord of the Danes, kept watch against a giant. Indeed the man of the Geats firmly trusted his brave strength and the favor of the Lord. Then he removed his mail shirt and the helmet from his head, gave his decorated sword, the best of weapons, to an attendant and ordered him to guard his war-gear. Then the good man spoke a boast: "I ${ }^{49}$ do not claim for myself lesser war-skills, deeds of battle, than Grendel himself.

Therefore I do not wish to kill him with a sword, to deprive him of life, though I am very well able to.

He does not know finer skills, so as to be able to strike me, to cut my shield to pieces, though he be renowned for hostile deeds. But we two shall, in the night, refrain from swordplay, if he dares seek out battle without weapon. And thereafter, wise God, the holy Lord, shall grant glory to whoever's hand as seems proper to Him." He then bent down, the battle-brave one; the cushion met the warrior's face, and around him many brave sailors lay down on the hall-bed. Not ${ }^{50}$ one of them thought that he would ever return from there to his homeland, to the people or village where he was raised. But they had heard 
READER'S NOTES AND TRANSLATION 
that far too many of the Danes in the wine hall had been seized before in death-slaughter.

But the Lord granted to them a war-victory weaving, comfort and help to the Wederas men that they entirely overcome their enemy through the strength of one by his selfsame might. Truly it is known that mighty God has forever ruled mankind. In blackest night he came, the shadow-walker moved. The archers sleptthose that must hold the horned-houseall but one. That was known to men, that ${ }^{51}$ if God did not wish it, the battle-demon could not heave them down into the shadows, but the fierce, wakeful foe, his heart spurred, awaited the result of battle.

\section{$\mathbf{X I}$}

Then Grendel came, scrambling from the moors under misty cliffs: he bore God's fury. The evil killer meant to capture some human in the hall, the high one. He advanced under cloud-cover until he was sure he knew the gilded wine-hall, golden gathering-place of men. Not that it was the first time that he had sought out Hrothgar's home. Never in the days of his life, before or after, did he find a harder fate among heroes. Then the striding warrior came to the hall, despoiled of joys. The door sprang quickly open, made ${ }^{52}$ fast with fire-forged bands, as he touched it with his hands. 721 Then with baleful intent, angered as he was, he ripped open the mouth of the hall. Immediately then the enemy trod forth on that patterned floor, angry of mood he advanced. From his eyes there shone a horrible light like that of fire.

He beheld in the hall many a warrior sleeping there together, a band of kinsmen, a company of young warriors. In his heart he then laughed, evil monster, for he meant to separate body and soul of many a warrior present there before the day dawned. There welled up in him there the expectation of his fill in feasting. But it was not to be that he should feast anymore upon mankind after that night. The powerful one observed, 
READER'S NOTES AND TRANSLATION 
Hygelac's ${ }^{53}$ brave kinsman,

marked how the ravager

would carry out his ambush.

The powerful one didn't think to pause

but at his first chance swiftly snatched up

a sleeping man, greedily tore at him,

crushed his bones, slurped blood from his veins,

gulped down bite after bite. Soon he had

devoured the dead man's feet, hands-

everything. The fiend advanced,

groped and grasped again

for the bold-hearted warrior in the bed.

Beowulf, grasping his hostile intent,

braced himself with his own arm.

Immediately the guardian of evil realized

that he had never encountered

$\mathrm{in}^{54}$ the corners of the earth, in another man

a greater hand-grip. He became in his mind

afraid at heart. None the sooner was he able to get away.

His mind was eager for him to depart, he wished to flee into a hiding place, to seek the company of devils. It was not his experience there

such as he met before in his life-days.

He remembered then, the good kinsman of Hygelac,

the evening-speech. He stood up

and seized him firmly. Fingers burst.

The giant was trying to escape; the warrior stepped further.

The famous one intended, where he might do so,

to go to a more remote place, and away from there

to escape into the fen-retreats. He knew the control of his fingers

was in the grips of the hostile one, that it was a sad journey

that the harmful destroyer took to Heorot.

The ${ }^{55}$ splendid hall rang. For all the Danes arose,

for the fortress-dwellers, for each of the bold ones,

for the warriors, great terror. Both were enraged,

the fierce hall-guardians. The building resounded.

It was a great wonder that the wine-hall

withstood the battle-brave ones, that it did not fall to the ground, the beautiful building. But for this it was firm,

inside and outside with iron bands,

53 Hilary E. Fox (ll. 736-750)

54 Joshua R. Eyler (1l. 751-765)

55 Rebecca Merkelbach (ll. 766-780) 
READER'S NOTES AND TRANSLATION 
fastened with ingenuity. There from the floor many a mead-bench bent away, as I have heard tell, adorned with gold, where the hostile ones fought.

They had not expected this before, the councillors of the Scyldings, that ever in any way any man might break apart the excellent and bone-decorated hall, destroy it with cunning, unless the embrace of fire might ${ }^{56}$ swallow it in flames. The sound rose up,

new and strange: shock and awe arose in the North-Danes, in every one who heard the wailing woe through the wall, God's enemy howling his agony, a song without triumph, Hell's captive wailing his pain. He held him fast, he who was the strongest man of might in that day of this life.

\section{XII}

The protector of earls did not wish at all to let that deadly visitor leave alive, and did not consider his life-days useful to any people. Around him, many an earl of Beowulf drew his ancient heirloom, wished to protect the life

of $^{57}$ the great prince, as they were able to do so.

They did not know it, when they endured battle, brave-minded warriors, and intended to strike on every side, to seek Grendel's soul: that no war-swords, best of swords, any over the earth, would touch the malefactor.

But Grendel had cursed weapons of victory, every blade. His death, on that day of this life, had to be miserable, and the alien spirit had to travel far into the dominion of his enemies. Then he who earlier carried out many afflictions of mind upon mankind, many crimes-he was guilty before God-then he found out 
READER'S NOTES AND TRANSLATION 
that ${ }^{58}$ his body would not avail him;

but that courageous kinsman of Hygelac

had him by the hand. Each was to the other

loathsome while living. The terrible adversary

weathered a body-wound. On his shoulder showed

a woeful wound plain to see, sinews sprang apart,

bone-links burst. To Beowulf was

granted battle-glory. Grendel had to

flee thence, life-sick, under the fen-slopes

to seek his doleful dwelling. He knew it more firmly

that his life's end was come,

the day-count of days. To all the Danes,

after that bloody battle, blitheness had come about.

He had then cleansed, he who before came from afar,

wise and brave, the halls of Hrothgar,

saved $^{59}$ them from strife. He rejoiced in his night-work,

826

his feats of courage. The man of the Geats had

fulfilled his boast to the East-Danes.

Likewise, he remedied all distress,

the sorrow that they had suffered before,

and the misery they had been bound to endure

no small grief. That was made evident

when the battle-fierce man placed the hand, arm, and shoulder-all of Grendel's grip

was there together-under the vaulted roof.

\section{XIII}

Then, in the morning, as I have heard it said,

there were many warriors around the gift-hall.

Chieftains traveled from far and near,

over the wide way, to behold the marvel,

the tracks of the enemy.

His death

seemed ${ }^{60}$ no sad thing to any man

of those who beheld the wretch's footsteps,

how he, wearied and on his way,

overcome with enmity, bore his mortal trudge

into the mere of the monsters, doomed and shunned.

58 Andrew W. Klein (ll. 811-825)

59 Nancy M. Michael (1l. 826-840a)

60 Eric Weiskott (1l. 841-855) 
READER'S NOTES AND TRANSLATION 
There the tide swelled with blood, a horrid surge of waves all mixed up with hot innards: it welled up with carnage; doomed, he hid himself when joyless he laid down his life and his heathen soul in his refuge in the fens, where hell received him. So then the old companions turned again along with many young men from the cheerful journey, brave ones from the mere riding horses, warriors on steeds. There, Beowulf's boldness ${ }^{61}$ was broadcast. Many of them muttered often there was no one...

no one northward nor southward, no one between sea and sea, no one walking the broad earth, no one beneath the bending sky, who was a better shield-wielder, nor was there any more worthy of a kingdom...

Though indeed by no means did those Danes lay blame upon their gracious lord, the kindhearted Hrothgar, for that was still a good king. Then sometimes they, horsebacked and battle-brave,

allowed their straw-colored steeds to leap forth, to journey on in playful contest with each other where the footways were fair and familiar.

Sometimes a king's servant, a man with a mind for myths and a head heavy with vaunting vows, recollected legends of long past heroes, an uncounted quantity; other words he found And he bound them together with true skill.

to animate the quest of Beowulf and craft a proper tale, transpose the words. He told all he had heard about Sigmund, of courageous deeds, many strange, the Waelsing's struggles, journeys wide, which the sons of men would not have known, wrath and violence, without Fitela, when he would speak

61 Jonathan Quick (ll. 856-870a)

62 Tiffany Beechy (1l. 870b-885) 
READER'S NOTES AND TRANSLATION 
uncle to nephew, as they were ever comrades in conflict.

Many kind of monster they had slain by sword. For Sigmund after death came no small fame since, battlehard, he killed the worm.

The ${ }^{63}$ guardian of the horde, he under hoary stone, 886 the son of nobles, alone attempted a daring deed, nor was Fitela with him. Yet he succeeded so that the sword pierced through that wondrous wyrm, so that it stood in the wall, that lordly iron. The dragon died of that destruction. That fierce combatant had gone in strength so that he could enjoy the ring-hoard of his own will. His sea-boat he loaded, bore into the bosom of the ship bright treasures, the son of the Wæls. The fierce worm melted. That was the wanderer most known wide throughout peoples, a protector of warriors, for bold deeds. So he first prospered. Long $^{64}$ after Heremod's battles ended,

Fought with strength and courage,

He was betrayed and sent away.

Among his enemies he quickly met his death.

For too long he had wallowed in misery and sorrow.

His people suffered as did his nobles.

In earlier times many wise men bemoaned

The plight of the strong willed miserable Heremod.

They had thought he and they would thrive.

Now they hoped the son

Would take his father's place and prosper,

Watch over their fortune, protect the people, and maintain the nation,

The realm of heroes, the home of the Scyldings.

Beowulf was held in high esteem, a friend to all.

Wicked miserable Heremod a dim dark memory.

Racing ${ }^{65}$ by turns, with horses they measured out

the bright street. By then morning light

too had hurried on. In firm mind

to see a puzzling wonder, many a man strode

63 Rebecca Straple (11. 886-899)

64 Chainy J. Folsom (11. 900-914)

65 Britt Mize (ll. 915-930) 
READER'S NOTES AND TRANSLATION 
to the hall so high. Likewise the king himself, guardian of ringhoards, stepped forth glorious from the spousal bower, conspicuous in his excellence, with a great company; and with him his queen measured the meadpath with a cohort of girls.

\section{XIV}

Hrothgar spoke up. He went to the hall, stood in a high place, looked at the lofty roof decorated with gold and Grendel's hand. "May our thanks speed to the All-Ruler for this sight. I have experienced many a hateful thing, many griefs from Grendel. But always God can work wonder upon wonder, the Protector of Glory.

It ${ }^{66}$ was not long ago that I did not expect

to see relief in this life

from any of my miseries while, stained with blood, the best of houses in slaughter stood, woe widespread; or each of the wise, those who could not hope to defend the people's stronghold from adversaries, demons and devils. Now a warrior, through the might of God, has done the deed which we could not do with all our cunning. Behold! It may well be said that whichever woman brought forth such a son among the race of men, if she yet lives, that the Old Measurer was gracious to her in childbearing. Now, Beowulf, best of men, as a son to me I will love you in my heart. Henceforth, hold well a new kinship. There will not be for you any lack of worldly wealth over which I have control. Very ${ }^{67}$ often for less I appointed rewards, an honoring with gifts for a lowlier warrior, inferior at battle. Thou thyself hast brought about with actions, that thy deed will live forever and ever. The Omnipotent One reward thou with goodness, just as He up to now has done."

66 Katayoun Torabi (ll. 931-949)

67 Damián Robles (1l. 950-961) 
READER'S NOTES AND TRANSLATION 
Beowulf spoke, son of Ecpeow:

"With much goodwill we brought about this fight,

work of valor, we dared audaciously

the strength of an unknown one. I wished more

that thou might have seen him,

the enemy himself killed among decorated arms.

$\mathrm{I}^{68}$ had intended to quickly bind him in

strong grasps in a bed of death,

so that he would have to lie struggling for life

on account of my hand-grip, unless he abandoned his body.

When the Lord did not wish it, I could not hinder him in going,

and by no means did I hold him, the deadly enemy,

so firmly. The fiend was too powerful

in his stride. Yet he left his hand,

arm, and shoulder to remain behind as a life-protection.

By no means did the wretched man

obtain any consolation there in that manner.

By no means will the evil-doer live longer

afflicted in wrongdoings, but the wound will have him

tightly seized in a malicious grip,

in evil bonds; there the outlawed man

shall await a great judgement,

how glorious God wishes to sentence him."

Then $^{69}$ Ecglaf's son was a more silent man

in his boasts of battle feats,

once nobles had inspected the hand,

up over the high roof through a warrior's craft-

the foe's fingers. The tip of each one,

in place of each fingernail, was just like steel,

a hand-spike of a heathen and a warrior,

grievous and ghastly. Everyone said

that no sword of the stalwart, no iron of old,

would touch him, would wound

the opponent's bloody battle-hand. 
READER'S NOTES AND TRANSLATION 


\section{XV}

Then quickly came the command that Heorot's interior $\mathrm{Was}^{70}$ to be decorated by hand. There were many to do this

Both men and women, they prepared the guest quarters

of the wine hall. Ornamented with gold the

Tapestries shone out from the walls. They were a wondrous

Sight for all to gaze upon.

That glorious building was broken.

The inside held fast in iron bands

The hinges of the doors burst apart. The roof alone

Survived completely intact when the wretched monster

Guilty of his wicked deeds turned in flight

Fearing for his life. It is not easy

To escape from death, try it who will;

We are obliged to seek, us with souls,

Earth dwellers and children of men,

To go to that appointed place

where ${ }^{71}$ his body, fixed in its grave,

sleeps after feasting. Then time was and season

that Healfdene's son should go to the hall.

The king himself would taste of the feast.

I've heard of no nation greater in force

better-behaved to their generous lord.

Then they bent to the benches, the keepers of fame,

rejoiced at the feast. They fittingly drank

many a mead-cup, kinsmen of theirs,

strong in their minds, in that high hall,

Hrothgar and Hrothulf. Heorot inside was

filled with friends. The People-Scyldings

not at all at that time showed signs of deceit.

Then Beowulf was given Healfdene's sword;

a golden standard as victory's reward,

the $\mathrm{e}^{72}$ adorned standard, helm, and byrnie.

Many saw the famous treasure-sword

brought before the hero. Beowulf took

the full flagon from the floor. Of the reward-gift he did not

as payment need to be ashamed.

I have not heard that more graciously four treasures

adorned with gold, many men

70 Sarah Hayes-Hickey (ll. 991-1005)

7I Robert Stanton (ll. 1006-1020)

72 Steven Modugno (ll. 1021-1035) 
READER'S NOTES AND TRANSLATION 
on ale-bench have given to others.

Around the helmet's roof, the head-guard

was wound with wires, the reinforced crest guarded from without

so that what the files have left could not savagely,

wondrously-tempered, harm him, when the shield-fighter

had to go against enemies.

The defender of earls then ordered eight horses, with decorated head-gear, led into the hall floor, in ${ }^{73}$ under the eaves. Upon one sat

a saddle decorated with works of art, adorned with treasure.

That was the warseat of the high king

when the son of Healfdene desired to perform

swordplay. At the front the widely-known warrior

never lay prone, when the corpses fell.

And then the lord of the friends of Ing

granted to Beowulf ownership of both,

horses and weapons. He bade him to use them well.

So manfully did the glorious lord,

hoard-protector of warriors, repay the storm of battle

with horses and treasures, that never could they be reproached by anybody who desires to speak the truth according to what is right.

\section{XVI}

Then the lord of earls to each

of those who with Beowulf took a sea journey

$\mathrm{on}^{74}$ the mead-benches gave treasures,

old heirlooms, and that one ordered

to compensate in gold the man whom Grendel earlier

sinfully slaughtered. As he more of them would,

except for them mighty God forestalled fate,

and on account of that man's courage. The Measurer ruled all

of the kin of men, as he now yet does.

Therefore is his intellect everywhere the highest

forethought of the mind. Much must one endure

of the lovely and the loathly he who for long here

in these conflict-days enjoys the world.

There was song and sound together at once

before the battle leader of the Halfdanes

the glee-wood was touched, a lay often recited.

73 James Eric Ensley (ll. 1036-1050)

74 Abraham Cleaver (1l. 1051-1080) 
READER'S NOTES AND TRANSLATION 
Then the hall-entertainment, Hrothgar's scop along the mead benches was obliged to tell of the sons of Finn, when the calamity befell them, the hero of the Halfdanes, Hnæf of the Scyldings, was fated to fall in the Frisian slaughter. Nor indeed had Hildeburh cause to praise the good faith of the Jutes. Guiltless, she was deprived of her loved ones at the battle-play, her son and brother. They fell to fate, wounded by the spear. That was a mournful woman. Not at all without cause, the daughter of Hoc mourned the decree of fate, after morning came. When she, under the sky, was able to see the slaughter of kinsmen. Where he previously held the greatest joy in the world, war took away all of Finn's thegns, except only a few so $^{75}$ that he could not in any way

fight any war against Hengest on the battlefield, nor could the survivors of woe drive out through conflict the lord's thegn. But to them they offered terms, that they would grant another home to them, hall and high seat, that they would share control of half with the sons of the Jutes.

And at the gifting of treasure the son of Folcwalda would honor the Danes each day, present Hengest's host with rings, even as much ornamented gold as he would have favored the Frisian people with in the beerhall.

Then they confirmed on both sides a fast peace-treaty. Finn to Hengest made ${ }^{76}$ oaths with unquestioned zeal

that with the judgement of his advisors he would maintain the honour of these survivors, that no man would break the oaths in word or deed, nor would ever mention through desire to harm that they were following the killer of their ring-giver, without their lord, as need impelled them.

And if any Frisian said anything dire to remind them of their murderous hate, 
READER'S NOTES AND TRANSLATION 
then the sword's edge would settle it.

The oath was prepared, and ancient gold

taken from the hoard. The War-Scyldings'

best warrior was ready for the flame.

It was easy to see on that pyre

the stained coat of mail, the swine all gilded

the $\mathrm{e}^{77}$ iron-hard boar, and many princes

stricken with wounds (some fell in the carnage).

Then Hildeburh commanded at Hnaef's pyre

her own son to be committed to the inferno,

the bone-cask to be carried and given up to the fire,

beside his uncle. The lady mourned,

she sang her lamentations. The warrior was taken up,

he flew to the clouds. The greatest of funeral pyres

roared beside the grave-mound. Heads melted,

gaping wounds ruptured, whilst blood gushed out

from that damned body-bite. Fire swallowed up entirely-

that greediest of spirits - those whom battle had taken

from both tribes. Their glory was gone.

\section{XVII}

The warriors left then to seek out their homes,

friendless, turning their gaze to Frisia,

to their homes and their capital.

$$
\text { Hengest }^{78} \text { as yet }
$$

remained the blood-stained winter with Finn

entirely undivided. He thought of his home,

although he might on the sea drive

the ring-prowed ship. The sea heaved in the storm,

fought against the wind; winter locked up the waves

in an icy bond, until came another

year to the lands, as it still does now,

those that continually observe the seasons,

the gloriously-bright weather. Then winter passed,

beautiful was the breast of the earth. The exile hastened

the guest from the dwellings. He of vengeance

thought exceedingly, rather than to the sea-course;

if he might accomplish a meeting with his foe,

77 Neville Mogford (ll. 1111-1126a)

78 Christine Voth (ll. 1126b-1140) 
READER'S NOTES AND TRANSLATION 
for he contemplated within the sons of the Jutes.

$\mathrm{So}^{79}$ he did not refuse the world's custom,

When Hunlaf's son placed the gleaming sword,

The best of blades, onto his lap.

Those edges were renowned among giants.

And thus cruel sword-torment happened then

To brave-minded Finn in his own home.

Later, after their sea-voyage, Guðlaf and Oslaf

Spoke of that sorrow, the grim attack,

Complained of their share of woes. A restless spirit could not

Be contained within the breast. Then the hall was bedecked

With the bodies of enemies, and Finn, too, was slain,

A king among his company, and his queen taken.

Scylding warriors carried to the ship

All of the earth-king's worldly goods,

All that they could find at Finn's home

of ${ }^{80}$ jewels and gemwork. On the sea, they

carried the noble lady to the Danes,

led her to the people. A song was sung,

a gleeman's tale. Games again arose,

and revelry resounded; cupbearers brought forth

wine out of wondrous vessels. Then Wealhtheow came forth,

walked beneath her golden crown to where those brave ones,

both of them, sat, nephew and uncle.

Still then was their bond intact, each

to the other true. Likewise, there Unferth the Orator

sat at the feet of the Scyldings' lord.

Every one of them trusted in his heart

that he had great spirit, though he to his kinsmen

was not honor-bound at swordplay.

Then said the lady of the Scyldings:

"Take ${ }^{81}$ this cup, my noble lord, giver of treasure. May you be in health, goldfriend of men, and speak to the Geats with mild words as a man ought to do. Be gracious with the Geats, mindful of gifts from near and far which you now have. Someone has said to me that you would have the warrior as a son. Heorot is cleansed, the bright ringhall. Enjoy while you may many rewards and leave community and kingdom to your kin when you must go forth to face your destiny.

79 Shari Horner (ll. 1141-1155)

80 Christopher Jensen (ll. 1156-1170)

8I Stacy S. Klein (ll. 1171-1185) 
READER'S NOTES AND TRANSLATION 
I know, my glad Hrothulf, that he will hold the young ones in honor if you, 0 Lord of the Scyldings, should leave the world before he does. "I ${ }^{82}$ trust that he will rightfully repay

Our children, if he thinks about everything

That the two of us gladly and honorably

Did for his sake when he was young."

Then she turned to the seats, her sons there Hrethric and Hrothmund, and warriors' boys, The gathered youth. There the good man sat, Beowulf the Geat, by the two brothers.

\section{XVIII}

They brought him the full cup with friendship An offering made good with words and gold, Two arm-rings were in friendship given, Armor and finery, and the greatest neck-chain That I have ever known there was on earth. No better has ever been heard of under the sky, In the precious hoards of heroes, since Hama stole the Brosings' necklace off towards the battle-bright stronghold, jewel and treasure-cup. He fled the treacherous hostility $\mathrm{Of}^{83}$ Eormanric chose eternal good fortune.

Hygelac the Geat, grandson of Swerting, Had that ring on his last venture, When under the banner he defended treasure, Defended slaughter-plunder. Fate took him, Afterwards, because of pride, he asked for misery, Feud against Frisians. He then carried the ornament, Precious stones, over the waves' cup, Almighty ruler. He fell beneath the rimmed shield. The body of the king passed then into the Franks' grasp, Breast-corslet and the ring together. Worse warriors rifled dead bodies After the slaughter in battle. People of the Geats Possessed the place of corpses. The hall received applause, Wealhtheow spoke. She spoke before the company: 
READER'S NOTES AND TRANSLATION 
"Beowulf, ${ }^{84}$ dear warrior, enjoy this circlet

in luck, and make use of this mail shirt,

treasure of a people, and prosper well,

be brave and strong, and to these boys be

benign in counsel-I will reward you for that.

You have brought it about that men will praise you

far and near, always and forever, just as widely as the seas, home of the winds, encompass the cliffs. Be while you live

fortunate, 0 prince! I wish you well

with these treasures. Be to my sons

proper in your deeds, as a benefactor!

Here each earl is true to the other,

mild in his mind, protects his lord,

the thanes united, the nation fully prepared;

the warriors, having drunk a pledge of loyalty, will do as I command."

Then ${ }^{85}$ she went to her seat. There was the choicest of feasts,

1234

Men flushed with wine. They knew not Wyrd,

Grim creation of old, as it had happened to come

To many of the earls when the evening came.

And with it, Hrothgar went towards his dwelling,

The ruler to rest. The hall held

A countless number of earls, as they often ere did.

They bared the bench-boards. It was overspread

With beds and bolsters. One of the beer-servants,

Ready and doomed, bowed to floor-rest.

Set by him, towards the heads, bossed shields,

Bright wooden boards. There on the bench, was

over $^{86}$ a prince easily seen

war-hardened helmet, ringed coat of mail,

stout spear. It was their custom

to be continually battle-ready

both at home and on campaign, wherever they were,

whatever occasion their lord

had need. They were a fierce band of brothers.

84 Larissa Tracy (ll. 1218-1233)

85 Kayla Kemhadjian (ll. 1234-1245)

86 John D. Lewis (ll. 1246-1260) 
READER'S NOTES AND TRANSLATION 


\section{$\mathbf{X I X}$}

Then they sank into sleep. One paid a sore penalty for slumber, as it very often came to pass, when Grendel visited the gold hall, performing evil until the conclusion came, death due to crimes. Evidenced, widely known, an avenger still lived after the hateful one, a long time after war-strife. Grendel's mother, the ${ }^{87}$ lady trouble-maker remembered misery, she, who had to inhabit the horrible water the cold currents, after conflict arose through Caina sword slayer to a solitary brother, a father's son. He went forth stained, marked by the murder, fled man's pleasures dwelled in the wild. From him awoke many doomed demons. Grendel was one of these, the fiendish savage foe who found at Heorot a wakeful man waiting for battle.

There the creature came to grips with him. Yet he remembered the mighty strength, the generous gift which God gave him, and he relied on the One Ruler's favor for security and support. By this he overcame the fiend, humbled $^{88}$ that hell-spirit. Then he departed, that foe of mankind, wretched, deprived of joy, to seek death's dwelling. And so his mother, ravening and brokenhearted, set out on her sorrowing way to avenge the death of her son. She came to Heorot, where the Ring-Danes Slept within the hall. Those inside soon suffered A grave misfortune when Grendel's mother Invaded their haven. The terror was the less Only so much as a maiden's skill, A woman's war-terror, compares to an armed man's When a well-gripped weapon, a hammer-forged And bloodstained sword with a keen edge, Carves through the boar-crest of the war-helm before it. Then in the hall hard-edged weapons were seized, 
READER'S NOTES AND TRANSLATION 
sword ${ }^{89}$ over seats, many broad-shields

held fast in hands. Helm not remembered, nor large byrnie, when that horror befell him. She was in haste, she wished out from there, to protect her life, when she was found out. Quickly she had one of the princes fast gripped, when she went to the fen.

That was Hrothgar's most beloved warrior in the retainer's role powerful warrior, between the seas, the glorious man. Beowulf was not there, for another dwelling was appointed earlier After the gift-giving, to the noble Geat. A cry arose in Heorot. She in gore took the famous arm. Sorrow was renewed, returned ${ }^{90}$ to the settlement. Nor was it a good exchange, that those on both sides should pay with the lives of friends. Then the wise king, the grey-haired warrior, was troubled at heart when he learned that his chief thegn no longer lived-his dearest companion was dead. Quickly, Beowulf, the victorious warrior, was fetched to the king's chamber. At daybreak the noble warrior went with his retainers to where the wise king waited, wondering whether God Almighty would ever improve his misfortune. Beowulf, the distinguished warrior, crossed the floor with his companions-the hall-wood resounded-and with words addressed the wise one, the ${ }^{91}$ leader of the Ingwings; he asked him if the night was agreeable to his desire.

\section{$\mathbf{X X}$}

Hrothgar spoke, leader of the Scyldings:

"Ask you not for joy. Sorrow is renewed for the Danish people. Æschere is dead, Yrmenlaf's older brother, my confidant, and my counselor, and the closest companion, when we in war defended our heads, when the foot soldiers clashed and struck the boar helms. An earl should be such, to be tried and true, Eshere was such a man!

89 Sarah Beah Jacobson (ll. 1291-1305)

90 Sara Schliep (ll. 1306-1320)

91 Abraham Cleaver (ll. 1321-1335a) 
READER'S NOTES AND TRANSLATION 
There arose before him in Heorot a hand-slayer a restless slaughtering demon. I know not whither the terrible one, glorying in the carcass, returned after it was made bold by its fill.

in which you killed Grendel last night

in a violent manner, with a hard grip, because for too long he diminished and destroyed my people. He died in the fight, forfeited his life. And now another has come, a mighty manslayer, she wishes to avenge her kin, and has taken vengeance too far in that feud, as it may seem to many a thane who weeps in his heart for his treasure-giver. Severe distress! Now the man lies lifeless, the one who supported you in all things.

This I heard earth-dwellers among my people, my hall-counselors, say:

that they have seen two such otherworldly spirits, great marsh walkers, holding the moors, spirits $^{93}$ from elsewhere. The second of the two bore, as far as men could certainly discern, the likeness of a woman. The other wretched one trod the paths of exile in the form of a man, yet he was larger than any other man.

That one in days gone by they called Grendel. Earth-dwellers never knew of his father nor whether any was born to him before, of evil spirits. They haunt a secret land, wolf-slopes, windy headlands, and fierce fen-passages, where an inland stream under the cliffs' mists descends, a flood under the earth. In mile-marks it is not far from here that the mere stands.

Over it hangs frost-covered groves, woods ${ }^{94}$ firm with roots stretch over the water.

Each night one can see there a horrible wonder, fire on the lake. No wise man lives among the sons of men who might know that depth.

92 Virginia Blanton (ll. 1335b-1350)

93 Alice Hicklin (ll. 1351-1365)

94 Sarah L. Higley (ll. 1366-1380) 
READER'S NOTES AND TRANSLATION 
If the heath-stepper, harried by hounds, the strong-horned hart put to flight from afar, should seek the woods, he would sooner give his life, his heart, on the bank, before he plunge in to hold on to his head. That is no lovely place! The mingling wave lifts up from it, dark to the clouds when the wind stirs a hateful storm, until the air grows wan and the heavens weep. Help depends now on you alone: yet this land you don't know: this perilous ground where you can find The ${ }^{95}$ sinful man. Seek him if you dare;

For that feud I will reward you with riches,

Ancient treasures, and twisted gold,

As I did before, if you were to come back safe."

\section{$\mathbf{X X I}$}

Beowulf spoke, the son of Ecgtheow:

"Grieve not, wise man. It is better for each man

To avenge his friend when he mourns greatly.

Each of us shall experience the end of

Worldly life; let him who may

Achieve glory before death. This is the best

For warriors, after they are dead.

Arise, ward of the kingdom, let us fare quickly,

To follow Grendel's mother's trail.

I promise you this: in no refuge shall she escape,

Neither in earth's bosom, nor in mountain forest,

nor ${ }^{96}$ the bottom of the ocean, let it go wherever it will. Today you

must endure every one of your troubles, as I believe you will." Then the old and wise one leapt to his feet, gave thanks to God, the mighty Lord, for the words that the man had spoken. Then a bridle was put onto a horse for Hrothgar, a steed with a braided mane. The wise leader, the magnificent one rode forward. The foot-soldiers advanced, carrying their shields. The tracks could be seen far and wide, paths through the forest. The creature had gone across the ground, travelled in a straight line over the dark waste-land, carried the young retainer, inanimate, the best of those who guarded the homestead with Hrothgar. Then the descendant of princes travelled 
READER'S NOTES AND TRANSLATION 
over ${ }^{97}$ steep stone cliffs, strait paths,

narrow tracks, an unknown way,

sheer headlands, many homes of water-creatures.

He fared in front with a handful

of experienced men to examine the way,

until he suddenly found mountain firs

leaning over leaden stone,

a desolate wood. Water stood below,

blood-red and roiling. For all the Danes

and their Scylding friends it was shocking

in their minds, for many men, to suffer,

anguish to each of them, when they found

on the sea-cliff Æschere's head.

The waves boiled with blood - the men beheld-

hot with gore.

Time ${ }^{98}$ and again a horn sang

$1425 b$

a ready war-song. The walking warriors all sat down.

They beheld in the water many a breed of serpents,

strange sea dragons exploring the waters,

sea monsters lying on the slopes of the headland.

In the early morning they often take

a sorrowful journey on the sail-road,

the serpents and wild beasts. They rushed away

fierce and enraged, heard the noise

of the singing war-horn. A man of the Geats

with a bow separated one of the wave-swimmers

from its life so that a hard war-arrow

stood in its body. It was slower

of swimming in the sea when death seized it.

In the waves it was swiftly hard-pressed

with barbed boar-spears,

with ${ }^{99}$ force attacked, and dragged onto shore,

the wondrous wave-roamer. Men gazed at

the terrible guest. Beowulf geared himself

with nobleman's armour, not at all fearful for life;

with his war-coat, hand-braided

broad and well-adorned, he was to explore the water,

that war-coat which could defend the bone-chamber

so that a war-grip may not harm his heart,

97 David Klausner (ll. 1411-1425a)

98 Anne Breyer (ll. 1425b-1440)

99 Gwendolyne Knight (ll. 1441-1455) 
READER'S NOTES AND TRANSLATION 
nor the ireful one's malicious grasp his life.

And also the shining helm guarded his head,

he who was to stir the depths of the mere

to seek the surging waters, that helm adorned with treasure,

encircled by noble chains as in ancient days

the weapons' smith wrought it, wonderfully worked it,

adorned it with boars, so that never thereafter into him

neither ${ }^{100}$ blade nor battle-swords were able to bite.

However that was not the meanest of mighty helps

that Hrothgar's orator lent to him in need.

Hrunting was the name of that hilted sword,

foremost among ancient treasures.

Its edge was iron, gilded with poison,

tempered by bloodshed. Never in battle did it fail

any man who grasped it with his hands,

who dared to go on grim journeys

into the folk-stead of the enemy. This was not the first time

it was obliged to accomplish valorous deeds.

Indeed he did not remember- the son of Ecglaf,

powerful of might - that which he spoke before,

drunk with wine, when he lent that weapon

to a more able swordsman. Himself he dared not

to risk his life under the turmoil of the waves,

to accomplish valor. He forfeited glory there,

renown for courageous deeds. It was not thus for the other man,

once he had armed himself for battle.

\section{$\mathbf{X X I I}$}

Beowulf ${ }^{101}$ spoke, son of Ecgtheow,

"Keep it in your mind, famous son of Halfdane,

Wise prince, now that I am eager for a journey,

Gold-friend of men, what the two of us spoke about earlier:

If in your need I should lose my life,

That you would always be as a father to me, even after I have departed.

Be a guardian to my young retainers,

my close companions, if battle takes me.

Likewise, send to Hygelac those treasures

that you have given me, dear Hrothgar.

100 Jerrod Rosenbaum (ll. 1456-1470)

I0I Joshua Byron Smith (ll. 1475-1485) 
READER'S NOTES AND TRANSLATION 
Then ${ }^{102}$ in that gold, may the lord of the Geats understand,

Hrethel's son see when he stares on that treasure,

that I with manly virtue found an excellent

distributor of rings, I used them while I could.

And you, let Unferth, the well-known man, have the ancient heirloom, the wondrous, wave-patterned, hard-edged sword.

I myself with Hrunting will accomplish victory or death will take me!"

After those words the man of the Weder-Geats

hastened with courage. He did not wish to wait for an answer.

The sea-surge received the warrior.

Then it took the length of a day

before he could perceive the ground.

She discovered this immediately, she who, sword-greedy,

held for a hundred half-years the expanse of the floods,

grim $^{103}$ and greedy, found that someone explored the dwelling

of monsters from above.

She seized at him, caught the warrior

in terrifying clutches; yet she didn't injure

the hale body within; the ring mail protected him from the outside

so that she couldn't pierce the war-covering,

the linked mail-shirt, with her loathsome fingers.

The sea-wolf bore the prince of rings to her home

when he came to the bottom of the mere

So that he couldn't-however brave he was-

wield his weapons, but so many strange creatures,

many sea beasts, drove hard through the water,

broke his army-shirt with battle-tusks,

dogged the assailant. Then the warrior knew

that he was in a certain hostile hall

where ${ }^{104}$ no water at all could reach him,

for the roofed hall would not let

the flood's grasp touch him. He saw firelight,

a beaming brilliance, brightly shining.

Then the good man saw that outcast of the deep,

the mighty woman of the mere. He gave a great blow

with the battle-sword-he did not hold back the hand swing-

102 Patricia O Connor (ll. 1486-1500)

103 Frances McCormack (ll. 1501-1515)

104 Alison Elizabeth Killilea (ll. 1516-1530) 
READER'S NOTES AND TRANSLATION 
his ring-adorned sword sang on her head a greedy war-song. Then the guest found that the battle-flame would not bite, nor harm her life, but the sword failed the prince in his need-before, it had often endured a clash of hands, had cut through armour, the war-gear of the doomed. That was the first time with the precious gift, that its reputation had failed. Afterwards, ${ }^{105}$ not at all lacking in zeal, he was of one mind,

The kinsman of Hygelac, mindful of glory:

He then threw the curve-marked sword, bound with ornaments, An angry warrior, so that it lay on the ground, Hard and steel-edged. He trusted in strength, A hand-grip of power. So must a man do, When he thinks to gain in battle Long-lasting fame. He never cares about his life. By no means did he mourn on account of the feud. He then seized by the shoulder The man of the Battle-Geats, Grendel's mother. Then when he was swollen with rage, hard in battle, he flung The life-enemy so that she sank onto the floor.

She quickly afterwards gave him requital In the grips of a fierce one, and seized him in return. Weary-hearted, the strongest of warriors, Of foot-warriors, made an attack, so that he was falling. She then pinned the hall-guest down, and drew her seax, Broad, brown-edged. She wanted to avenge her child, Her one son. On his shoulder lay A woven breast-net; that protected life, Against sword and against edge, stood against entry. The son of Ecgtheow would have perished, The champion of the Geats, under that broad ground, If the battle-net had not brought help to him, The hard battle-mail. And holy God Controlled the battle-victory. The wise Lord, The ruler of the heavens, decided it on the right side, Easily. Afterwards he stood up again. 
READER'S NOTES AND TRANSLATION 


\section{XXIII}

He saw among the war gear a victory-blessed sword, An ancient sword made by giants, strong in its edges, worthy ${ }^{106}$ sword of warriors the best of weaponsbut it was more than other men could bear to battle-sport, good and richly geared, a work of giants. The Scyldings' strong one seized the linked hilt, savage and sword-grim, drew the ring-marked sword spurning his life, angrily struck so that the sword sank deep in her spine, broke bone-rings; the blade bit through the fated flesh, she fell on the floor; the blade was bloody, Beowulf exulted in his work. A gleam glittered, stood glowing within even as the sky's candle shines brightly from heaven. He gazed through the hall; then Hygelac's thane turned to the wall hefted his weapon firmly ${ }^{107}$ by the hilt, the thane of Hygelac angry and resolute. Nor was the blade useless to the warrior, but rather he wished at once to repay Grendel for the many assaults which he had carried out against the West-Danes, much more often than on one occasion, when he the hearth-companions of Hrothgar slew in their slumber, devoured while they were sleeping fifteen men of the Danish folk and as many again he carried off, a loathsome plunder. He paid Grendel back for this, the fierce warrior, insofar as he saw on his resting-place the battle-weary Grendel lying lifeless, as he was injured in the battle at Heorot. The corpse sprang wide open when ${ }^{108}$ he suffered a blow after death,

a hard sword stroke, and then he cut off his head.

Shortly after, the wise men perceived that.

With Hrothgar, they looked on the water that was a turmoil of waves, all mixed up,

106 Robert Jesse Stratton (ll. 1561-1575)

107 Aidan Conti (ll. 1576-1590)

108 Dana M. Oswald (ll. 1591-1605) 
READER'S NOTES AND TRANSLATION 
a surf stained with blood. The salt-and-pepper-haired

old men spoke together about the great man:

that they had no hope thereafter for this prince-

that he, victory-triumphant, might seek to come again

to the most famous chief. Many agreed to this,

that the female sea-wolf had destroyed him.

Then came the ninth hour of the day. They abandoned the headland, the sharp Scyldings. He departed towards home from that place,

The gold-friend of men. The guests in that land looked longingly around

Sick in spirit, and stared at the mere,

wished, ${ }^{109}$ and did not believe that they would

see their lord-friend himself. Then that sword,

after battle-sweat, into battle-icicles,

the war-blade began to wane. That was a thing of wonder,

that it all melted away, most like ice,

when the Father releases the binding of frost,

unwinds the deep water's fetters, who holds dominion

over seasons and time. That is the true Creator.

He did not take to those dwellings, the man of the Wether-Geats,

more treasures, though he saw many there,

except for the head and the hilt together,

gleaming with treasure. The sword already melted,

the inlaid pattern burned up. That blood was so hot,

the poisonous departing-spirit who died in that place.

Soon, he was swimming, who had earlier endured that fight, the $\mathrm{e}^{110}$ fall in battle of enemies. He thrust up through the water.

The churning waves were entirely cleansed-

a huge expanse-since that fierce monster

had given up her days of life and all these fleeting works.

Then the defender of the sea-warriors reached land,

swimming vigorously. He revelled in the heavy load

of lake-treasures which he had with him.

Then they went towards him, gave thanks to God,

a mighty band of warriors, they rejoiced in their prince

because they could see he was safe.

Then helm and mail were quickly loosened

from that powerful man. The lake grew calm -

the cloud-covered water - stained with corpse-blood.

109 Ilse Schweitzer VanDonkelaar (ll. 1606-1620)

I 10 Chris Jones (ll. 1621-1636) 
READER'S NOTES AND TRANSLATION 
From there they went onwards along footpaths, happy in their hearts, they traced the track, the familiar way. Kingly-brave men, from $^{111}$ the sea-cliff they bore the head

\section{XXIV}

Beowulf proclaimed, Ecgtheow's son:

"Listen, Healfdene's son, we this sea-offering

have brought to you, prince of the Scyldings, with pleasure, as a token of glory that you here may gaze on.

I with difficulty escaped with my life,

a war under water, a work ventured with hardship. Very nearly was

The battle finished, except God protected me.

Nor could I at the battle with Hrunting accomplish anything, even though that weapon was fit.

But to me the God of men granted

that I saw along the way a bright, powerful sword hanging. 
READER'S NOTES AND TRANSLATION 
those ${ }^{113}$ without protecting friends; so that I drew the weapon, then struck in that skirmish, when the occasion allowed me, the keepers of the house. Then that battle-blade, pattern-welded, burned up when the blood spurted, hottest of hostile-sweats. From there I ferried that hilt away from enemies, their wicked deeds avenged, the violent deaths of Danes, just as it was deserved. I bestow it to you, then, so that in Heorot you may sleep without sorrows with your company of warriors, and each of the thanes of your people, old and young; you need not fear for them, Prince of Scyldings, on that frontmortal harm for your nobles-as you did before."

Then the golden-hilt was handed over to the wise old warrior, grey-haired battle-chief, work $^{114}$ of wonder-smiths; and when that one gave up this world grim hearted man, adversary of god, guilty of murder-and his mother tooit came into the keeping of the best of the world-kings between the seas of those who deal treasures in Scandinavia. Hrothgar spoke, scanned the hilt, the old leaving on which was written the origin of the ancient struggles, when the flood, the rushing sea, eliminated the race of giants. That went badly. That race was alien to the eternal lord; their final retribution came through the whelm of water the ruler sent. Thus ${ }^{115}$ it was upon the guard-plates of bright gold, through runic letters duly marked, set down and stated for whom that sword was first wrought, the choicest of blades, twisted hilt and dragon-patterned. Then the wise one spoke, Son of Healfdene. All fell silent.

"Well, now, he who furthers truth and right among the people, an aged ward of the realm who remembers all the distant past, may say that this warrior was born the better man.

I I 3 Tom Birkett (ll. 1666-1680)

I I 4 Damian Fleming (ll. 1681-1695)

I 5 Christopher Monk (ll. 1696-1710) 
READER'S NOTES AND TRANSLATION 
Glory is spread throughout the wide ways, O Beowulf, my friendyours over every nation. All this you patiently hold, strength with wisdom of heart.

I shall fulfil my friendship toward you, just as we two spoke earlier. You shall become as a refuge, long-lasting, ${ }^{116}$ to your people,

and be a help to those heroes. Heremod? Not so much

to the Honor-Scyldings, those sons of Ecgwala.

Neither did he drive the Danes to their desires, but their deaths and destruction.

Enraged, he razed the friends at his table and brothers at his shoulder, so that he, that infamous king, turned alone from the joys of men.

Nevertheless, the mighty God raised him up over all men, exalted him in the joys of power and strength.

Yet, in his innermost spirit, he grew bloodthirsty in his beating heart.

And never, not at all, not once did he give rings to the Danes chasing fame. Joyless, he survived until he suffered the pain of his strifethe eternal torment of man. Now, learn from this, understand virtue. This tale is for you, crafted out of my wintered wisdom. It is wonderful to tell how God almighty, to mankind, measures out wisdom, domain, and dominion through His own sovereign Spirit. He has power over all. Sometimes, He sets free the mind of a famed man (from a famous people) to find his own delight, the earth's joy. He gives him a home and a city of men to hold; He sets under his supervision a share of the world, a kingdom of such expanse that, for all his unknowing, he may not imagine for himself its borders. The man lives in luxury. None may distract himneither sickness, nor old age, not even evil thoughts cloud his mind. Not ever does malice or war-mongering materialize, but all the world bends to his will. He knows nothing worse. 
READER'S NOTES AND TRANSLATION 


\section{XXV}

Eventually, ${ }^{117}$ the allotment of pride within him

waxes and grows. Then the protector sleeps,

the soul's shepherd. This sleep is too deep,

bound with anxieties; the Slayer is very close-

who sinfully shoots the bow.

Then he struck in the heart, under the helmet, with a bitter arrow, he doesn't know how to protect himselfthe perverse commands of evil spirits.

What he has too long possessed seems too little;

angry and covetous, he does not honorably give

golden rings, and his future destiny

he forgets and neglects, that which previously God granted to him,

the Lord of wonders: his allotment of honor.

It $^{118}$ happens afterwards, in the end,

1756

that his borrowed body perishes,

falls fated for death. Another takes over

who deals out the treasures, the earl's ancient property,

without grieving. He does not heed fear.

Guard yourself against wickedness, dear Beowulf,

most excellent man, and chose better,

eternal counsels for yourself. Pay no mind to pride,

famous warrior. Now is your power's glory-

for a while. Immediately afterwards

illness or the blade will strip away your strength,

or fire's grasp, or sea's surge,

or sword's bite, or spear's flight,

or terrible old age. Or your eyes' brightness

will fail and dim. Soon enough it will come about

that death overwhelms you, warrior.

1771

Consequently, ${ }^{119}$ I for half of a hundred years, have had the power over the Ring-Danes beneath the heavens, and by battle have held away clans throughout this world, by ash-spears and weapons, so that I considered on no enemy under the sky of heaven. Indeed, accordingly to my home there came a return of fortune, grieving after joy, when Grendel, old enemy, became my intruder. I perpetually felt the suffering of that calamity. Gratitude to God for that, to the eternal lord, that in my abode I can look with my own eyes on this sword-dreary head after ancient strife. Now at this time go to your 
READER'S NOTES AND TRANSLATION 
seat-place, ease yourself into the feast, battle distinguished, many treasures between us shall be shared after morning."

The ${ }^{120}$ Geat was glad of it and immediately went

to seek out a seat, as the wise man commanded.

As before, speeches were uttered again

in an elegant manner for the powerful man

and again for those sitting in the hall.

The shadow of night drew in, dark over the warriors.

The noble troop all arose, for the aged, grey-haired Scylding

wished to seek out his bed. The Geat, too,

the brave shield-bearer, felt an unmeasurable

desire for rest, and so a hall-thegn immediately

guided out the one who had come from afar

and who was weary from his journey.

Out of respect he attended to

the thegn's every need, whatever in those days

such sea-faring warriors should have.

Then the great-hearted man rested.

Lofty and shining with gold, the hall towered up;

inside the guest slept until the cheery black raven

announced the joy of the sky:

the time when brightness came gliding.

The warriors were in haste;

nobles were eager to sail home again,

back to their people, and the bold-hearted visitor, too,

wished to visit his ship and travel far from there.

Then the hardy one commanded

that Hrunting be presented to the son of Ecglaf.

He commanded Unferth to take back his precious iron sword, and he gave him thanks for the loan.

He said that he considered it

a good and powerful friend in battle-

and no, he did not reproach the edge of the sword.

That was high-minded of the man!

And ${ }^{121}$ when the warriors were there, eager to go,

with their armor equipped,

that nobleman stepped forth, honored among the Danes,

towards the high seat where the other one was.

Brave by battle in hell, he addressed Hrothgar.

I 20 Jennifer Neville (ll. 1788-1815)

I2I Ryan Lawrence (ll. 1816-1845) 
READER'S NOTES AND TRANSLATION 


\section{XXVI}

Beowulf spoke, son of Ecgtheow:

"Now we seafarers, having come from far away, wish to tell you that we desire to seek Hygelac. Here we have been happily entertained with delights. You treated us well. If I can do any thing else on earth to earn more of your mind's love, than the battle-deeds I have done already, ruler of men, then I will be ready at once. If ever I hear from across the ocean that neighboring people threaten you with terror, as your enemies formerly did, I will bring you a thousand thanes, heroes as help. I believe in Hygelac, the lord of the Geats, though he may be young, shepherd of his people, that he will support me with words and deeds, that I might honor you well and deliver a forest of spears to help you, the support of my strength, if you are in need of men. Then if Hrethric himself determines, king's son, to come to the Geat's houses, he will find many friends there. Distant lands are better sought by one who is himself good." Hrothgar spoke and answered him:

"The wise Lord has sent those words into your heart. I have never heard $\mathrm{a}^{122}$ man hold forth more wisely at such a young age.

You are strong in might and sage in mind, wise in what you say. I give my opinion: if it should happen that a spear seizesa bloody fierce battle- Hrethel's heir, sickness or sword takes your lord, the people's keeper, and you have your life, the Sea-Geats would not have a better king, treasure-guardian of warriors, for the choosing, if you should wish to rule the realm of your relatives. Your spirit pleases me more and more, beloved Beowulf. By your actions, between the people there will bebetween the Geats and the Spear-Danes- 
READER'S NOTES AND TRANSLATION 
shared friendship, and strife will sleep, hostilities ${ }^{123}$ that they carried out before;

and as long as I hold the broad kingdom, we will share wealthpeople will greet each other with goods over the gannet's bath.

Ships will bring gifts and love tokens over the waves. I know our people remain staunch both in friendship and in enmity, blameless in every respect according to the old ways."

Then and there the protector of warriors, the kinsman of Healfdane, gave him twelve gifts. With those gifts in the hall he told him to have a safe journey to his own people, and come back again soon.

Then the king, lord of the Scyldings, good to noblemen, kissed the best thane and took him by the neck. Tears fell on him from $^{124}$ the grey-haired one. He anticipated two things, the old and very wise one, the second thing more strongly, that they would not be allowed to see each other afterwards, the proud ones in a meeting. The man was so dear to him that he could not restrain his breast-welling. But in his heart, fixed with heart-strings, he longed secretly after the dear man, with blood he burned. From there, Beowulf, the warrior proud with gold, walked onto the grassy ground, exulting with treasure. The ship waited for its owner; it rode at anchor. Then, in its going, the gift of Hrothgar was often praised. That was a singular king, otherwise blameless, until old age took from him the joys of strength; it often harms many.

\section{XXVII}

Then ${ }^{125}$ came to the sea the brave-hearted

young warriors, bearing chainmail, linked war-shirts. The land-warden saw the return of the nobles, as he did before. He did not with insult from the cliffs greet the guests, but he rode toward them, said his welcome to the Weder people, those bright-armored warriors, went to the ship.

I 23 Robin Norris (ll. 1861-1875)

124 Thijs Porck (ll. 1876-1890)

125 The Medieval and Renaissance Student Association, California State University, Long Beach; Kimberlee Flack, Donald Burke, Jeremy Cooley (ll. 1891-1905) 
READER'S NOTES AND TRANSLATION 
Then on the sand, the sea-worthy boat was laden with war-clothes, the ring-prowed ship with horses and treasure. The mast towered over Hrothgar's treasure-hoard. Then, he gave to the boat-warden a goldbound sword, so that later on the mead-bench he was worthier by that treasure, that ${ }^{126}$ heirloom. He went out in the boat to stir the deep water, left the land of the Danes. Then a certain sea-garment next to the mast, a sail, was made fast with a rope. The sea-wood groaned. Thereafter the wind over the waves hindered not the wave-floater on its way. Forth over the swell that sea-goer fared, floated foamy-necked, a bound-stemmed vessel over the ocean-streams, until the crew could perceive the cliffs of the Geats, the familiar bluffs. The ship shot forward and up, driven by the strong wind. It stood on the land. Quickly at the water was the harbor-guard readythe one who, for a long time, alert at the coast, had been looking far out for the much-loved men. He moored to the shore the roomy ship anchor-cable ${ }^{127}$ fast, lest the wave's heaving should drive away those pleasing beams.

Then he commanded a prince's treasure to be carried up, ornaments and pressed gold. They needed not go far to find the giver of riches, Higelac the Hrethling, waiting there at home himself with companions, near the sea-wall. Great was that dwelling, brave the King, in his high-hall. Queen Hygd very young, wise and well-proven, though few winters she had dwelled beneath the stronghold-roof, Hæreth's daughter. She was nevertheless not stingy, nor too miserly to the people of the Geats, with gifts of treasure. Modthryth, famous folk-queen, committed a terrible crime. 
READER'S NOTES AND TRANSLATION 
None ${ }^{128}$ of the 'fierce' fighters but her husband dared to gaze upon her eyes after that doomed day. For him, the protection of those perilous-peers was prescribed, twisted by her hand, and swiftly subjected to almighty agony. After the grasp of hands, a falchion was fashioned so that it may infamously cut to declare deadly evils. It was not quite the queenly behaviour one wants from a woman, but she was peerless, that peaceweaver, denying after dubious distress the lives of commendable kinsmen. Regardless-one drunken aledrinker disclosed that Hemming's hooded hero came after that, after which she needed not to advance assaults or artful enmity, when $^{129}$ it happened,

she was given gold-veiled to the young hero,

noble beloved, to Offa's hall

over the flashing waves, because of her father's counsel, she sought to sail.

For ${ }^{130}$ a while afterward she made good

$1954 b$

use of her condition in life and her place on the throne, celebrated for her goodness. She held a deep love for the lord of heroes: the best of all mankind, as far as I know, the best of all the human race between the two seas. Because of this, Offa was a spear-keen man in gifts and in war, honored far and wide, and he held the power of his homeland through wisdom. From him came Eomer, a help to heroes, Hemming's kinsman and Garmund's grandson, cunning in the face of strife.

\section{XXVIII}

With ${ }^{131}$ his hand-picked troop, the brave one himself

went along sand to tread the sea-plain,

the broad beaches. The world-candle shone,

sun eager from the south. They had performed that journey,

courageously went to the protector of earls,

the slayer of Ongentheow, deep inside the fortress;

they knew the good, young battle-king

was disbursing rings. Beowulf's arrival was

immediately reported to Higelac:

that the protector of warriors was in the precinct;

a shield-companion had arrived living, unharmed from the battle-play,

I28 Laura Creedon (1l. 1936-1950a)

129 Natalie Whitaker (1l. 1950b-1954a)

130 Courtney Catherine Barajas (ll. 1954b-1965)

I3I Brian O'Camb (ll. 1966-1995a) 
READER'S NOTES AND TRANSLATION 
to walk toward the court. The floor within was quickly cleared for the foot-guests, just as the ruler commanded.

Then he sat himself down, he who had survived the conflict, one kinsmen facing the other as soon as the lord of men greeted the loyal one through diplomatic discourse, with earnest words. With mead cups making rounds throughout the hall, Haereth's daughter showed love to the people as she bore the drinking vessel into the hands of heroes. But Higelac began to question his comrade courteously in the high hall-curiosity about what happened on the journey of the Sea-Geats broke him:

"How did it go with you on your trip, dear Beowulf, when you suddenly thought to seek conflict far off over the salt water, battle at Heorot? Did you better the well-known troubles of Hrothgar, the famous prince, even a little bit?

\section{Because $^{132}$ of that I brooded with}

$1995 b$

sorrowful cares, with anxiety in my heart; I did not have faith in the journey of a dear man. I pleaded with you for a long while that you should not visit that murderous creature at all, that you should allow the South-Danes to handle the battle with Grendel themselves. I say thanks to God because I am able to see you whole."

Beowulf spoke, child of Ecgtheow: "That great encounter is not hidden from many men, Lord Hygelac, what time of pain Grendel and I shared together in the place where he performed measureless sorrows, constant miseries for the Victory-Shieldings. I avenged all that, thus less the evil of Grendel's kin over the earth needs to boast about the night-clash, whoever ${ }^{133}$ lives longest of that hateful race, seized utterly by sin. Once there, I came first to the ring-hall, to hail Hrothgar.

Straightaway that great son of Healfdene - as soon as he grasped my heart's thoughtspointed me to a seat with his own sons.

The troop took its pleasure. Never have I seen in the breadth of my life under heaven's course a greater joy among hall-sitters for the fellowship of mead. From time to time, the resplendent queen, the peace-bond of peoples, turned about the floor, 
READER'S NOTES AND TRANSLATION 
bolstered the young boys, and often gave a winding of gold to a warrior, before going back to her seat.

And again and again, before the assembly of noblemen, Hrothgar's daughter carried the ale-cup to each in turn.

Then I heard the men gathered on that floor call her Freawaru as she poured from the studded treasure for those brave ones. It is said she is betrothed, that gold-decked maiden, to the gracious son of Froda. The Scyldings' caretaker has made this come to pass, the friend to his kingdom, for he trusts the counsel that by means of this bride he may buy off the feud, this share of slaughter. Very seldom, though, after a nation's fall, does the murdering spear lay low for long, no less so for a blameless bride. It will be displeasing to the prince of the Heathobards and to every one of the thanes of that people, when he crosses the floor with that woman: the high-born of the Danish troop, so well-received, on them shimmering the spoils of ancient bounty the ring-mail and close-hewn treasures of the Heathobardsthe while they were able to wield those heirloom weapons.

\section{$\mathbf{X X I X - X X X}$}

Until $^{134}$ they have led their loved ones

and their own lives into destruction in shield-play.

Then, the old spear warrior who sees the ring, he who remembers the spear-slaughter of men, will speak at beer-drinking-his heart will be bitter within himSad of spirit, he will begin to test a young warrior, To awaken war-strife through thoughts of the breast and he will say these words:

'Can you, my friend, recognize the sword, the precious blade which your father under an army-helm carried to battle for the last time? There the Danes, the brave Scyldings, slew him; they controlled the slaughter place since Withergyld lay dead, after the fall of heroes. 
READER'S NOTES AND TRANSLATION 
Now $^{135}$ the son of one or another of those slayers,

exulting in weapons, walks on the floor of the hall, boasts of murders, and wears the treasures that you rightfully should possess.'

Thus he urges and reminds on every occasion with bitter words, until the time comes that the woman's thane for his father's deeds sleeps bloodstained after the sword's bite, having forfeited life. The other one thence escapes alive-he knows the land well.

Then the oath of earls will be broken on both sides. After that, deadly hate boils up in Ingeld and in him love for his wife after seething sorrow, becomes cooler. Therefore I do not consider the Heatho-Bards' loyalty a measure of sincere peace with the Danes, a firm friendship. I ought to go on telling further about Grendel, that you will know well, giver of treasure, what came after of the warriors' handfight. After heaven's jewel glided over the earth, the angry demon came, dire night terror to attack us, where we, safe, guarded the hall. There Hondscio was taken in battle, by deadly evil fated to die. He first lay dead, belted champion. Famous young thane, Grendel was his devourer, the body of the beloved man all swallowed up. Yet not before out of there emptyhanded the bloody-toothed slayer, intent on destruction wanted ${ }^{136}$ to go out of that goldhall.

But he, strong, made trial of my strength, gripped with eager hand. A glove hung, wide and strange, secured with well-wrought bands;

it was dexterously all adorned with demonic skill and dragon skin.

To put me in there, innocent, that dire leader desired to do, as one of many. He might not do it, once I in anger stood upright. 
READER'S NOTES AND TRANSLATION 


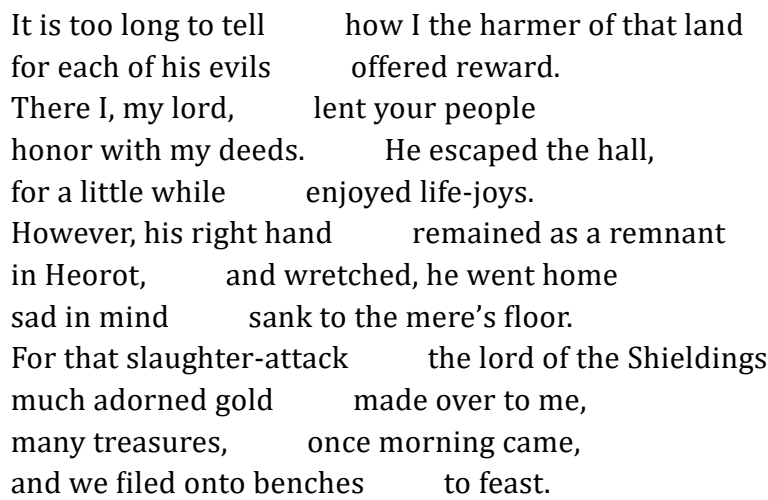

There was song and music. An elder of the Shieldings, knowing much, narrated times long past.

Sometimes the one daring in battle the harp's delight, the joy-wood played; sometimes he performed a song true and sad; sometimes a wondrous story. He recounted rightly, the generous-hearted ruler. Sometimes again began the old one to bind in story, the elder battle-warrior, to recall youth, war-strength. ${ }^{137}$ Heart surged within, when he, wise with winters, recalled so much.

So all-day-long inside there we took our pleasure, until night came, following upon men. Then quickly Grendel's mother was ready to avenge her wrong. She journeyed full of sorrow; death had taken her son, war-hate of the Weders. The fierce woman avenged her son, killed a warrior boldly; there from Æschere, the wise old counsellor, the life was departed. Nor were they able, once morning came, the Danish people, to burn him, death-weary, with brands, nor to place him on the fire, the beloved man; she took that body away into the fiend's embrace under the mountain-stream. That was the harshest of griefs for Hrothgar, of those which had long befallen the people-chief. Then the prince, troubled in mind, for your life implored me, that I, in the tumult of the waves, should perform a noble deed, risk my life, 
READER'S NOTES AND TRANSLATION 
achieve glory; he promised me reward.

I then, in that surging water, as is widely known,

found a fierce, terrible guardian of the bottom of the lake.

There for a time we two fought hand-to-hand;

water welled with blood, and I cut off the head,

inside that deep hall, of Grendel's mother,

with mighty edges. Not easily did I get away from there

with my life. I wasn't doomed for death just yet.

But afterwards the protector of warriors gave me

Many treasures, Healfdene's kinsman.

\section{$\mathbf{X X X}$}

$\mathrm{So}^{138}$ the king bowed to custom.

I had not lost sight of the reward, might's mead, Healfdene's son gave me gifts to match my glory's thirst. To you, king of men, I will bring treasures, present them with grace. All favours are yet owed to you. I have few close kinsmen, Hygelac, excepting you."

Then he bid them bring in the boar's emblem, the battle-high helmet, the grey horror-coat, the patterned war-sword; a speech followed:

"Hrothgar gave this battle-gear to me, wise king. He asked that first I might say something of its story: he spoke of how it was long held by King Heorogar, man of the Scyldings, yet he did not wish to give that chest-mail to his son, brave Heoroward, loyal though he was. Bear it well." I heard that four apple-brown steeds came swiftly in the wake of the war-gear; he bestowed on him the gift of treasure and horses. So a kinsman should, instead of weaving, with dark craft, a net of deceit, devising the death of a comrade in arms. To Hygelac, 
READER'S NOTES AND TRANSLATION 
strong when laid low, his nephew was steadfast, each looked out for the other.

$\mathrm{I}^{139}$ heard that he handed over to Hygd

that neck-ring-

the one which Wealhtheow had willed unto him,

daughter of a lord,

the intricately-crafted marvel-treasure-

together with three horses

graceful and gleaming in their saddles.

Afterwards, upon the receiving of that ring, her breast was embellished.

So did the son of Ecgtheow show himself stalwart;

a man familiar with fighting, and with good deeds.

He bore himself to a strict standard:

not in the least did he drunkenly slay his hearth-companions,

nor did trouble harry his heart.

But, battle-brave and with the keenest skill,

he kept hold to that great gift which God had granted him.

Actually, for a long time, he was miserable

because the sons of the Geats thought him no good at all,

and the lord of the Weders wish to make him worthy of much on the mead-bench.

They solemnly swore he was slothful,

an enfeebled freeloader. But there came to that famous man

a turning-about of his fortune for every hardship he suffered.

Then $^{140}$ the protector of warriors,

the brave in battle king, commanded to be brought in

the heirloom of Hreðel, adorned with gold;

not at all among the Geats then was there

a better treasure in the form of a sword.

That treasure he laid in Beowulf's lap

and gave him seven thousand hides of land

a hall and a princely seat. To both together was

inherited land in that nation, a home and ancestral right,

but the more broad kingdom was for the better one.

In turn it took place in later days

in the crash of battles, after Hygelac lay dead

and for Heardred the battle swords under the

shields became killers,

when the Battle Scylfings, the hard warriors, 
READER'S NOTES AND TRANSLATION 
sought him among the victorious people attacked with hostility the nephew of Hereric.

I $^{141}$ was then that the broad kingdom came

into Beowulf's hands; he held it well

for fifty winters-wise was then the aged king,

old guardian of the land of the Geats-till one began

to dominate in the darkness of the night: a dragon

who in his high dwelling kept watch over his hoard,

a steep stone barrow, beneath it a path lay

unknown to all. Inside there one man went,

unnamed, who happened to come upon

the heathen hoard, his hand seized a treasure

of shimmering stones.

$$
\mathrm{He}^{142} \text { later learned }
$$

$2220 b$

he'd been swindled while asleep,

conned by a thief's guile. For that, the people-common folk

and landed lords-would live his wrath.

\section{XXXII}

$\mathrm{He}^{143}$ was not at all of his own accord

of the craft of the treasure held by the serpent,

of his own self's will he who sorely injured him

because of painful constraint a thief, I know not which

sons of men fled hostile blows,

in need of a place and there in entered

a man racked by guilt immediately it befell him there.

Then against the stranger terror stood

however ... upon the wicked one ... obtained peril.

He sought a gold vessel there were so many

in that earth-hall, ancient treasures

as they in days of yore, an unknown man

a great legacy of a noble kind,

thoughtful, had hid there

precious treasures all of them consumed by death

in earlier times; and then were again one

of the multitude of that people, he who moved the longest

the watchman, mourning for friends, he went to delay that

so that he for a little while, the long obtained treasure

I4I Miguel Gomes (1l. 2210-2220a)

142 Helene Scheck (1l. 2220b-2223)

I43 M. R. Rambaran-Olm (ll. 2224-2247) 
READER'S NOTES AND TRANSLATION 
would be able to enjoy. A hill all-ready

remained in the ground near the water's waves,

new by the headland fixed by the art of imprisonment;

there inside bore of the treasure of earls

a hoard of rings, a hand-wrought part

of ornamented gold; he spoke a few words:

"Earth. ${ }^{144}$ You now hold what now men cannot,

what warriors had.

That's not all: earlier, the good ones took this from you.

But a hostile death, a life-hack of evils

overtook every one of my people-

each of them gave it all up, the hall-joys they had seen.

He has nothing, who would wear a sword,

or offer up the rich cup, that dear drink.

Go look for glory somewhere else.

The hard helmet, decked out in gold,

must lose its shimmer. The scrubbers sleep-

those who should shine the battle-masks.

And the full-metal-jacket that endured combat, over the breaking of shields and the bite of iron, this falls apart without the man.

The ring-mail will not get far

without the war-lord, without the hero inside.

There was now no harp's joy, no glad-beamed mouth, no fine hawk swinging through the hall, no swift horse Beat ${ }^{145}$ hooves in the borough. Brutal death has

Sent forth too many of mankind."

Thus, sad in mind, he spoke of sorrow,

Alone after all, unhappy he roamed

Day and night until death's wave

Overwhelmed his heart. The worm found hoard-joy,

Ancient scather of dawn, a barrow standing open

For one who, seething, seeks out treasure.

The naked dragon flies by night, wicked,

Encircled by flames. All who dwelt on earth

Beheld him with dread. He must hunt out

Evil in the ground, where he guards heathen gold,

Old, wise in his winters, the people's harm

Held as his store-house a hoard in the ground,

144 Martin Foys (ll. 2248-2265)

I45 Shannon Godlove (ll. 2266-2280) 
READER'S NOTES AND TRANSLATION 
exceedingly ${ }^{146}$ powerful, until a certain one made him

swell with anger in his heart. To his lord he bore

a goldplated cup, begged for a pact of peace

from his lord. Then the hoard was ransacked, the hoard of rings was diminished. Favour was granted

to the wretched man. The lord gazed

at the ancient work of men for the first time.

Then the dragon awoke, strife was renewed.

He moved swiftly along the stone, hard-hearted he discovered

the footprint of the enemy. He had stepped forward

with stealthy skill near to the head of the dragon.

Thus an unfated man may easily survive

misery and exile, who the Ruler's

favour retains. The guardian of the hoard searched

eagerly along the ground, he wished to find the man,

the $\mathrm{e}^{147}$ one who sorely troubled him as he slept.

Hot and wrathful-minded, often he encircled the barrow

and all around outside. Although he found no man

in that wilderness, still he prepared for war,

for battle-work. Sometimes he returned to the barrow,

sought the treasure-cup. But he soon found again

that some man had discovered the gold,

the best of treasures. The Hoard-guardian waited

miserably, until evening came.

Then the barrow-watcher swelled,

would repay with fire the theft

of the precious cup. Then was the day passed

to the delight of the worm. No longer must he lie behind the wall,

did he have to wait, but he went forth with bale-fire,

infused with flame.

It was a terrible beginning

$2310 \mathrm{~b}$

to $^{148}$ the people in the land, as it soon became

to their treasure-giver a sore end.

I46 Laura Varnam (ll. 2281-2295)

I47 Lisa Weston (1l. 2296-2310a)

I48 Janet Schrunk Ericksen (ll. 2311-2325) 
READER'S NOTES AND TRANSLATION 


\section{XXXIII}

Then the visitant began to spew flames, to burn bright buildings. The gleam of fire stood in hostility to humankind. The hated sky-flier wished to leave nothing alive.

The warfare of the worm was widely seen, violence of the intensely hostile one, near and far, how the destroyer hated and harmed the people of the Geats. To his hoard he afterwards hurried, the hidden splendid hall, before daytime.

He had surrounded the people of the land with flame, fire and burning. He trusted his barrow, warfare and wall. The expectation deceived him. Then the terror was made known to Beowulf quickly ${ }^{149}$ in truth, that his own home, best of buildings, melted with burning flames, the gift-seat of the Geats. For the good one that was misery in his heart, the greatest of mind-sorrows. The wise man believed that he had bitterly angered the Ruler, eternal Lord, contrary to the old law. His chest welled within with dark thoughts, as was not typical for him. The fire-dragon had destroyed the fortification of the peoples, the stronghold, land by the sea from without with fire. The war-king, prince of the Weders, plotted vengeance for that.

The protector of fighters then commanded them to fashion, lord of heroes, a wholly-iron, wondrous war-shield. He knew well that ${ }^{150}$ no forest-wood might help him at all, no linden shield, against flame. The long-ago-proven prince must await the end of departing days of worldly life, and the worm as well, though he long held the hoard-wealth. The ring-holding prince rejected the thought that he might attack the wide-flier with a great army. Not at all did he dread the battle, nor did he dread the worm's war-making in any way, his strength and valor, because he long ago had often dared close encounters with hostile enemies,

149 Jordan Zweck (ll. 2326-2340)

150 Thomas A Bredehoft (ll. 2341-2355) 
READER'S NOTES AND TRANSLATION 
and battle-clashes, since he, a man blessed with victory, had cleansed the hall of Hrothgar, and at war grappled with the race of Grendel, hated folk. Nor was that the least of ${ }^{151}$ the hand-to-hand struggles, where one slew Hygelac: when the king of the Geats, in the assaults of battle, the people's beloved lord, in Friesland, the son of Hrethel, died by a thirsty sword, struck with the blade. Beowulf came away from there by his own might: he performed a swimming feat. He had on his arm thirty pieces of battle-gear in all, when he went to the sea. The Hetware had no cause to boast of that fighting on foot, those who carried shields against him; few came back from that battle-hero to find their home. Then the son of Ecgtheow swam across the sea's expanse, the miserable, solitary one, back again to his people.

There, Hygd offered him treasure and rule, rings ${ }^{152}$ and royal seat. Her son she trusted not, that against the alien army, the ancestral seats he could hold fast. Thus was Hygelac dead. Still the bereft could not prevail upon the prince in any way, that he would become lord over Heardred, or that kingship he would choose.

Yet he kept himself among people with friendly counsel, gladly with honor until he became older, he held sway over the Weather-Geats. The exiles sought him over the sea, the sons of Ohtere. They had rebelled against the lord of the Scylfings: the best of the sea-kings, of those in Sweden who dispensed treasure, the renowned ruler. For him that became the limit of life. There ${ }^{153}$ he obtained a useless life-wound by strokes of the sword, son of Hygelac. And the child of Ongenðeow again departed to seek out his home after Heardred lay dead. 
READER'S NOTES AND TRANSLATION 
He left Beowulf to hold the throne, to rule the Geats. That was a good king.

\section{XXXIV}

He remembered recompense for the fall of the prince.

In later days, Eadgils became

a friend in poverty. With people, he assisted

the son of Ohtere widely over the sea,

with warriors and weapons. Then he took vengeance afterwards

with cold sorrowful courses, deprived the king of life.

So he had survived each of the enmities,

of the cruel conflicts, the son of Ecgðeow,

works of valor, until one day,

when ${ }^{154}$ he had to go forth against the serpent.

He set off then, one of twelve, swollen with rage,

the lord of the Geats, to look for the dragon.

Then he found out where the feud had arisen,

the baleful malice of men. The infamous treasure-cup

came into his keeping, through the hand of an informer.

He was the thirteenth man in that throng,

he who brought about the beginning of that battle,

the sad-minded servant. The wretched one had to lead the way

from there to the field. He went against his will

to where he had knowledge of a certain earth-hall,

a barrow under the ground near the surging sea,

the warring waves. Inside it was full

of jewels and wire ornaments. The fierce guardian, the ready warrior held the golden treasures,

old $^{155}$ under earth. That was no easy bargain,

to be undertaken by any man.

Then the violent-hard king sat on the ness,

while he offered luck to his hearth-companions,

gold-friend of the Geats. A mournful mind was his,

restless and ruin-eager. Wyrd immeasurably near

that which should greet the aged man,

to seek his soul-hoard, split asunder

life from body. Not long after that was

the life of the æepeling enclosed in flesh.

154 Megan Cavell (ll. 2401-2415)

I55 Micah James Goodrich (ll. 2416-2430) 
READER'S NOTES AND TRANSLATION 
Beowulf spoke, the son of Ecgtheow:

"In youth I survived many war-rushes, many battle-hours. I remember all of that.

I was seven-winters when the prince of treasures lord-friend of the people, took me from my father.

King ${ }^{156}$ Hreðel kept and held me, gave me treasure and hospitality, mindful of kinship. I, a man in his residence, was not ever at all more loathly to him than any one of his sons, Herebeald and Нæðcyn or my Hygelac. A deathbed was unfittingly spread for the eldest by the deeds of his kinsman, when Hæðcyn injured him, his lordfriend, with an arrow from a horn-bow, missed the mark and shot his kinsman, one brother shot the other with a bloody missile. That was an unatonable fight, wickedly done, with a weary heart. Nevertheless the prince had to lose his life unavenged. Thus it is sad for an old man

$\mathrm{To}^{157}$ endure that his son rides

Young upon the gallows. So he makes a lament,

A song of sorrow, while his boy swings

To the pleasure of a raven. And he can't help him:

Too old and enfeebled to do anything.

Always will he be reminded each morning

Of this child's passing. Nor can he consider another

Awaiting him within some refuge or redoubt-

Another protector of his good works-when this one

Compelled through death is finished with his deeds.

With weary heart, he views his son's rooms-

gathering place abandoned, sleeping quarters too airy-

Riven of joy. Knights in unending sleep,

Heroes lain in darkness. There is no play of the harp,

No play in the courts as once there was.

\section{XXXV}

Then ${ }^{158}$ he retreated to his bed and sang songs of sorrow, one after another; everything seemed too spacious to him, the premises and the dwelling. "In this way the protector of the Weders dragged on his life, grieving, with heartfelt sorrow for Herebeald; there was no way at all to settle with the slayer a compensation for the crime; yet he could not persecute the battle-warrior for his abject deeds, though

I56 Erin M Shaull (ll. 2431-2445)

157 Patrick W. Conner (ll. 2446-2460)

I 58 Rolf H. Bremmer Jr (ll. 2461-2490) 
READER'S NOTES AND TRANSLATION 
he was not happy about it. Then he, to whom the pain had occurred, with that sorrow gave up the pleasures of men, went for God's light; he bequeathed to his heirs, as each fortunate man does, land and towns, when he departed from this life.

Then hostility and strife were brought about across the wide water between the Swedes and the Geats, fierce violence, after Hrethel had died, until Ongentheow's heirs became bold warriors, impetuous frontline fighters, who refused to honour peace across the water, but often inflicted horrible, pernicious wounds on the flanks of the Rysenbjerg. My dear kinsmen took revenge for it, with a violent tit for tat-the news spread; still, one of them had to pay for it with his life, a tough bargain. The battle proved fatal to Hæthcyn, lord of the Geats. Then, the next morning, I heard that one brother avenged the other on the killer with the edge of the sword, when Ongentheow encountered Eofer. The battle-helmet was shattered, the old Scylfing collapsed, deathly pale. His hand remembered plenty of hostile acts, it did not hold in the deadly blow.

$\mathrm{At}^{159}$ war, with a flashing sword, I repaid him those precious things that he had given me as was my lot.

He gave me land, a place, a home.

Nor was there any need for him, that he ought to seek

among the Gifthas

or among the Spear-Danes

or among the Swedes

a worse warrior,

or to buy one with gold.

I have always gone before him in the ranks,

alone at the front,

and so I always must

wage war

while this sword lasts, that has often availed me-long before and ever aftersince I barehanded killed Dæghræfn, champion of the Hugas in front of everyone.

No, he could not bring back that gear, that neck-ring, to the Frisian king, but he fell among the warriors

a guardian of the standard

a noble one in his bravery

nor was a blade his death

but I crushed his ribcage

broke the surging of his heart. 
READER'S NOTES AND TRANSLATION 
hand and hard sword, fight for the hoard."

Beowulf made a speech, spoke boastful words

one final time: "I survived many

a bold battle in my youth; yet I will,

as an old guardian of old folk seek a feud,

and garner glory, if the evil one will

leave its earth-hall and attack me in the open."

He then addressed each of his men,

Those bold-helmed warriors one last time,

trusted companions:

"I ${ }^{161}$ would not bear a sword,

$2519 b$

a weapon to the dragon, if I knew how

it could be otherwise

to grapple honourably, as I did before with Grendel.

But there I expect hot deadly fire,

fierce and venomous. I would not flee

by the space of a foot from the keeper of the cave.

It will turn out at the wall

as fate, the Lord of every man,

dictates for us. At heart, I've courage enough

to forgo arms against this flying fighter.

Men in armour, protected by chainmail,

wait on the cliff for whichever of the two of us

survives the wound

after the deadly battle.

This is not your venture,

nor is it in the power of any man, save me alone."

$\mathrm{He}^{162}$ knew he was to spend his strength on the adversary,

perform bravery. "With valor must I

get the gold, or else the battle,

the fierce fatal attack, will take away your lord."

Then he stood up by his shield, the renowned warrior,

hardy beneath the helmet, he wore a battle-shirt

under the stone cliffs, he had faith in the might

of a single man. The path of the spineless is not such!

Then by the wall, he who, great in goodness,

had survived scores of battles,

the crashes of clashes when troops contend,

160 Melissa Ridley Elmes (ll. 2509b-2519a)

I6 I Robin Smith (ll. 2519b-2534)

162 Alexandra Reider (11. 2535-2550) 
READER'S NOTES AND TRANSLATION 
saw the stone arches standing, a stream bursting forth thence from the barrow. There was a gush of water hot from harmful fires; no one could survive deep inside, near the hoard, for any length of time without burning because of the dragon's flame.

Out ${ }^{163}$ from his breast then, swollen with anger,

The Weather-Geats' leader let loose a cry,

Roared, stark-hearted; his voice rang in

Beneath grey stone, a clear call to battle.

Hate was aroused when the hoard-guard knew

The voice was a man's. No time remained

To sue for peace. First there shot forth

The fierce one's breath out from the stone,

Steaming hot, hostile, shaking the ground.

At base of barrow the warrior swung his shield, Lord of the Geats, to face the ghastly foe When the ring-coiling one was roused in its heart

To seek out strife. Had drawn his sword

The good warrior-king, an ancient heirloom,

Its edges undulled.

To ${ }^{164}$ either was

intending destruction

a terror from the other.

He stood resolute

with towering shield

friend of lords, when the wyrm coils

together at once;

he in war-gear waited.

It departed then burning bending to gliding

hastening towards fate. Shield well protected

life and limb for less time

the glorious king than his desire

there he for the first time for the first day

had to possess that fate did not grant to him

glory in battle. Hand raised up

lord of Geats, struck the multicolored terror

with the relic of the Danes, that the edge gave away

bright on the bone, it bit less strongly

than its lord had need,

subdued by its labors. 
READER'S NOTES AND TRANSLATION 
Then, ${ }^{165}$ after the war-blow, the barrow's warden felt a rage inside, $2581 \mathrm{~b}$ Spat deadly fire; the flames of war erupted.

The Geat's gold-lord did not boast of victorious triumphs:

His naked war-blade failed when he needed it, Although it shouldn't have, the legendary iron.

Nor was that an agreeable trip, when the glorious son of Ecgtheow

Felt compelled to surrender ground;

Against his will, he had to make a home elsewhere, As do all when they let go their loaned days.

Nor was it long before those two monsters met once more.

Again, the hoard-warden braced himself, his breast boiled with spirit; The other, enveloped by fire, was in a tight spotHe who used to lead his people.

Nor did his companions, sons of princes, throng to him With warriors' virtue, but they turned to the woods, Protected their lives. In one of them The heart swelled with sorrow; nothing can ever Turn a thoughtful man away from his family.

\section{XXXVI}

He was called Wiglaf, son of Weohstan, Beloved shield-bearer, man of the Scylfings, Kinsman of Elfhere. He saw his king, In his battle-helmet, suffer from the heat. Then he remembered the honors which were given to him before, The rich estate of the Wæmundings, all his father's privileges;

Then he could not hold back. He took his shield in hand, The yellow wood, drew the old swordIt was known to everyone as the legacy of Eanmund, Ohthere's son. A friendless pariah, he was killed in battle by Weohstan, Who delivered to his kinsman a shining helmet, Ringed mail, and an old, monstrous swordOnela gave that back to him as a gift, his nephew's war-gear, Immaculate soldier's trappings, but he did not mention His crime, though he killed his brother's child. Weohstan held that treasure for many years, The sword and chainmail, until his own child could Perform manly feats like his father had done. Then, among the Geats, he gave Wiglaf the war-gearAn inestimable amount-when he left this life, 
READER'S NOTES AND TRANSLATION 
wise $^{166}$ in course. That was the first journey

for the young champion, that he should face

the rush of battle with his lord-friend.

His mind's spirit did not melt, nor did the legacy of his kinsman

weaken in war. The wyrm found that out,

after they had come together.

Wiglaf made a speech, spoke many right words

about their companion. His spirit was mournful.

"I remember that time, where we took mead,

when we promised to our lord

in the beer-hall, to him who gave us these rings,

that we would repay him for the battle-gear,

if just such a need should befall him,

helms and hard swords. For this he chose us in the host,

for this journey, of his own will.

$\mathrm{He}^{167}$ deemed us worthy of renown, and gave me these treasures-

2641

for he judged us spear-warriors good, brave helmet-bearers,

- even though he planned, our lord, to carry out this glorious deed

alone: the guardian of his people! For he alone among all men

has achieved most glory-he acted without a second thought!

And now the day has come that he, our liege-lord, has need of strength

from sturdy warriors. Let us go, then, to help our battle-chief,

for as long as this beast, the savage fire-fear, remains! For my own part,

God knows, I would much rather that with my gold-giver my body should

embrace the flames! Nor does it seem fitting to me that we should

bear our round shields back home, unless beforehand we might

destroy the enemy, defend the life

of the lord of the Weders.

$$
\mathrm{I}^{168} \text { know well }
$$

That he, for all his past deeds shouldn't have to go this alone

Out of all the Geats suffer this affliction

And fall in battle; for us, sword and helmet

Mail coat and war armor must be shared for both of us."

He waded through the slaughter smoke, bore his war-helmet

To help his prince. He spoke a few words:

"Beowulf my Beowulf, hold on and well

As you in your days of youth said,

That that you would never allow your renown to decline

I66 Brandon W. Hawk (ll. 2626-2640)

167 David T. H. Baker (ll. 2641-2655)

I 68 Damian Fleming (1l. 2657b-2687) 
READER'S NOTES AND TRANSLATION 
As long as you should live. Brave in deeds you must Protect your life, resolute prince, With all your might. I will help you."

After these words, the angry wyrm came, The terrible malicious fiend, made another move Hostile, adorned with billows of flame, it sought its enemies Those hateful men. He came with waves of flame and Consumed every bit of the shield. His mailcoat wasn't able To offer protection to the young spearman,

But the young man went courageously Under his kinsman's shield when his own was Destroyed by flames. Then the war-king once again Thought on his glorious deeds, struck out with his Battle sword with all his might until it struck its head Compelled by hate. Nægling shattered, Beowulf's sword failed in battle, Old and grey. To him it was fated That blades of iron could never Help him in battle. His hand was too strong The man who asked too much of every sword, as I have heard.

When he took into battle a weapon hardened by wounds, he was not the better for it. Then ${ }^{169}$ for a third time the ravager of a peoplethe terrible fire-breathing dragon, enmity in its mind, rushed to the heroic one when a chance was offered to it, burning and battle-fierce. It closed its sharp teeth through the hero's throat. Beowulf was reddened with his life-blood; a sanguinolent stream surged out.

\section{XXXVII}

I have heard told that in the hour of need of the king of a people a warrior at his side made known his boldness, the skill and the courage that nature bestowed upon him. He did not heed the head, and thus his hand was burnt as the brave man came to the help of his kinsman and smote the hostile creature a little lower down, the warrior in armour, so that his sword, woven in gold patterns, sank in. Afterwards, the fire started to fade. The king himself then mastered his senses again, drew his dagger, 
READER'S NOTES AND TRANSLATION 
deadly and battle-sharp, that he carried in his corslet; the Lord of the Windloving people drove it to the serpent's heart. The enemy fell-his life vanquished by their valourtogether side by side they had destroyed it, two princes of one house. Such should a man behave when his thane is in need! This was the prince's last moment of glory for his own deeds, the last of his labours in this world. The wound, which the earth-dragon had earlier inflicted on him, started to sear and swell. Beowulf then understood that in his breast welled up the deadly evil, poison ${ }^{170}$ from within. Then the hero went,

until by the wall wise in thought he sat on a seat. Looked at the giants' works how the stone arch pillar fixed enduring earth-house would be held within. To him then with hands bloodstained famous leader the good warrior without measure his friendly lord refreshed with water, battle wearied, and his helm unfastened. Beowulf spoke. He spoke about the wound, Deadly wound. Knew he well That he in the space of a day had experienced Earth's joys. Then all was gone In a number of days, death exceedingly near: "Now to my son I would wish to give War-garments, if fate had granted to me thus Any heir afterward To my body belonging. I ruled the people For fifty winters. There was no folk-king Of any neighboring peoples Who me for a war-friend dared to attack, With terror oppressed. I on earth remained By destiny, held my own well, Did not seek treacherous quarrel, nor did I swear many Oaths wrongfully. I can of this all, With mortal wound weakened, have joy, Because the Leader of men did not need to lay at my charge Slaughter of kinsmen, when departs my life from body. Now you quickly go look at the treasure under the hoary stone, 
READER'S NOTES AND TRANSLATION 
dear ${ }^{171}$ Wiglaf. Now the serpent lies, sleeps sorely wounded, plundered of its treasure. Be swift now, so that I can see the riches of ages past, the store of gold, can look clearly on the bright crafted gems; so that I can more easily after a wealth of treasure leave behind my life and the people that I long ruled."

\section{XXXVIII}

Then, I have heard, the son of Wihstan in accordance with the spoken words immediately obeyed the wounded lord, the one stricken in battle, and wearing a ring-net, a shirt woven for battle, went under the barrow's roof. Then, as he passed the seat, the brave young thane, triumphant in victory, saw a multitude of precious jewels, gold glittering on the ground, wondrous things on the wall, and the lair of that serpent, the old flyer before daybreak; and ewers, vessels of long-ago men standing without one to burnish them, deprived of their decoration. There was many a helm, old and rusting, many arm-rings twisted with skill. Treasure, gold in the ground, can easily overpower any one of mankind, let him hide it who will. He saw, too, a standard all of gold hanging high over the hoard, the greatest of wonders made by hand, woven with dexterity. From it a light shone out so that he could see the floor's expanse and look over the wrack. Of the serpent there was no sign at all; a sword edge had carried it off. Then I have heard that the hoard was plundered in the barrow, ancient work of giants, by a single man, hefting ${ }^{172}$ to his chest goblets and dishes according to his own judgment; he seized as well the banner, the brightest of testaments. By now the sword-for its edge was iron-had already scathed the guardian of the old lord's treasure, who for a long time inflicted terrible fire, scorch-seething hot upon that hoard by many a midnight, until he died by violence. The eager messenger was in haste to return, impelled by the treasures; concern was breaking him as to whether he might find the bold-hearted Beowulf alive in that open place where the prince of Geats was, where he had left him earlier with failing strength. Then Wiglaf, with those treasures, found his blood-soaked lord, the renowned prince, 
READER'S NOTES AND TRANSLATION 
at ${ }^{173}$ the end of life. He afterwards began

to wet him with water until the point of a word

broke out of his breast-hoard.

Gloomy, the old man regarded the gold:

"For these riches I give thanks to the Ruler

to the World-King I say these words

to the Eternal Lord for that which I look on

which for my people I was permitted

to deliver before the day of my death.

For this treasure hoard now I trade

the sacrifice of my old life. Attend still

to the people's needs. I cannot be long now.

Let those renowned in battle make a barrow

bright once I am burnt on the bluff beside the sea.

As a reminder to my people it must

rise $^{174}$ high, up on the whale's headland,

so that seafarers-those who propel their ships

from far away, across the darkness of the seas-

come to call it Beowulf's Cliff."

The brave-minded king took from his neck

a golden torc; he gave to his servant,

the young spear-warrior, a gold-adorned helmet,

an arm-ring, and his mail-coat. He commanded him to use it well:

"You are the last of our kin,

the descendants of Wægmund. Events have swept away

all my kinsmen, warriors in their bravery,

to their ordained end. I must follow them."

That was the last utterance of the heart-thoughts

of that old man, before he chose the funeral pyre,

hot battle-flames. From his breast departed

his soul, seeking the judgment of the righteous.

\section{$\mathbf{X X X} \mathbf{X}$}

Then ${ }^{175}$ it had befallen the young man

sorely, that he saw on the ground

his dearest friend at life's end,

wretchedly bearing. Likewise lay the destroyer,

eldritch earth-dragon reft of life,

173 Josephine Nolan (ll. 2791-2805)

174 Alaric Hall (ll. 2806-2820)

175 Andrew T. Eichel (ll. 2822-2836) 
READER'S NOTES AND TRANSLATION 
balefully beaten. The coiled wyrm no longer

could wield the ring-hoard,

for iron-edges had ruined him,

hard war-scarred leavings of hammers,

so that the sky-flier, stilled by wounds,

fell to the stone near the hoarding.

Never after will he wheel and sail the air

at midnight, glorying in the treasure-trove,

revealing his bulk, but he fell to earth

from the war-leader's handiwork.

Indeed ${ }^{176}$ few mighty men on earth-though I have heard that they

were daring in their deeds-might have gained from that fight, should they have rushed into the poisonous foe's breath, or, finding that guardian dwelling in his barrow, stirred his ring-hoard with their hands. Death paid for Beowulf's share of the treasure: the end of their loaned lives came for each of them then, and it was not long until those late to battle abandoned their ticket, weak oath-breakers who before had, ten at once, not dared fight with spears in their lord's great need.

But $^{177}$ yet they were ashamed to bear shields,

war-garments, where the aged one lay.

They looked upon Wiglaf. He sat wearied,

the foot-soldier near his lord's shoulder.

He wished to rouse him with water-for him that did not at all succeed.

Nor might he on earth, though he longed for it very much,

hold onto the life in that chieftain,

nor change anything of the Ruler's.

The judgment of God would control deeds

for each of men, as he now yet does.

Then was from that young one an angry answer

easily begotten, for him who previously his bravery forsook.

Wiglaf declaimed, the son of Weohstan,

a man sad in soul. He looked at the unfaithful ones:

"That, alas, may say he who would speak the truth, that ${ }^{178}$ this lord, who gave treasures to you all,

cavalry-ornaments, which you stand in there,

when often he gave on the ale-bench

to people sitting in the hall, helmet and corslet,

the chief to his thanes, the mightiest of such

I76 Matt Roots (1l. 2837-2850)

177 Leah Pope Parker (ll. 2851-2865)

178 Carla María Thomas (ll. 2866-2880) 
READER'S NOTES AND TRANSLATION 
either far or near that he could find, which battle-garments he plainly bitterly cast away, when battle seized him.

The king of the people not at all needed to boast; still, God allowed him, Wielder of victories, so that he himself advanced, alone with a sword, when he was in need of strength. I could give him only little life-support in battle, and nevertheless I began to help my kinsman beyond my measure. Ever ${ }^{179}$ the worse, when I struck with my sword, was the deadly foe, fire less fiercely heaved from his head. Too few defenders thronged about our lord when his time came. Now the taking of treasure and giving of swords, all the joys of home for your kin, shall end. Each man of your tribe will wander, deprived of his land-right, once far-flung nobles hear of your flight, your dishonorable deed. Death is better for an earl than a life of shame."

\section{$\mathbf{X L}$}

He ordered the battle-work made known to the camp up by the bluff, where the band of brothers sat with mournful minds all the morning long, shield-bearers, ${ }^{180}$ in expectation either of the final day, or of the return of the beloved man. On few of the new tidings was he who rode the headland silent, but he spoke truly over all:

"Now is the wish-giver of the Wederas' nation, the lord of the Geats, fixed to his death-bed settled on the seat of the slain because of the serpent's deeds. Beside him lies his fatal foe sick with sax-wounds; he could not with his sword on that fiend in any way 
READER'S NOTES AND TRANSLATION 
wreak wounds. Wiglaf sits

over Beowulf, son of Weohstan,

one earl over the other unliving,

he holds a head-vigil, weary in mind,

over the beloved and the loathed. Now on the nation is the expectation

of a time of war, when revealed

to the Franks and the Frisians the fall of the king

widely becomes. The feud was shaped

harshly against the Hugas, when Hygelac came

faring with the fleet onto the Frisians' land.

There the Hetware humbled him in battle

with an overwhelming show of strength; it happened in courage

that the byrnie-clad soldier had to bow down.

He fell among footsoldiers. No treasures at all gave

the lord to his retinue. Since then, to us

the Merovingian's favour has been denied.

Neither ${ }^{181}$ peace nor favour

I expect from the Swedes, for it was wide known

that Ongenðeow severed Нæðcyn from life

the son of Hrepel, near Ravenswood,

when for pride the Geats first

attacked the warring Scylfings.

Soon the wise father of Othere,

old and fearsome, returned the onslaught,

destroyed the sea-king, rescued his wife:

an old woman deprived of her gold,

Onela's mother and Ohthere's.

And then he hunted down the Geats, his mortal foes,

until they fled with great trouble

into the Ravenswood, lordless.

Then with a huge army he assailed them, the remains of his sword, wound-weary survivors. Often all along the night, he threatened misery to that wretched army,

he promised he would, in the morning, on the sword blade

gut $^{182}$ open some on the gallows-trees

as amusement for his soldiers. Once more comfort came

to the sad-hearted ones, together at early day,

when they the horn and trumpet of Higelac,

their sound they heard, when the strong one came

to the proven warriors of the people traveling on the track.

I8I Erika Corradini (ll. 2923-2940)

182 Nathan John Haydon (ll. 2941-2955) 
READER'S NOTES AND TRANSLATION 


\section{XLI}

That bloody trail of Swedes and Geats, the bloody onslaught of men, was widely seen. How those people with him awoke hostility! Then he went, the brave one, with his kinsmen, old, downcast, to search for his stronghold.

The noble Ongentheow went farther away, he had heard of Higelac's battle-mastery, the war-craft of the bold one. He had no faith in resistance, that he might withstand the sea-men, defend ${ }^{183}$ the hoard, children, and women

from those traveling to battle. From there the old man

afterward made for underneath the earthwall. Then was chase given

to the Swedish people, Hygelac's banner.

They forged ahead across that field of refuge,

as the Hreðlings crowded toward the enclosure.

There Ongenðiow was, gray-haired,

brought to a halt by blades, swords

so that the king should submit

to the sole judgement of Eofor. Angrily

Wulf Wonreðing struck him with a weapon,

such that, owing to the hit, blood sprang forth

in streams below his hair. He was not afraid, however,

the old Scylfing, but quickly repaid

that assault with a worse exchange,

when ${ }^{184}$ the people's king returned.

Not sufficiently swift was Wonred's son

to finish off that aged noble,

he who cut through that helmet into his head

so that he, covered with wicked enemy blood,

fell to the ground. Not yet destined to die,

he saved himself despite the wound touching him.

It was allowed to the rugged servant of Higelac

with his broad sword, when his brother fell,

to raise his ancient gigantic sword over that colossal helmet,

over the protective shields. Then the beaten ruler -

guardian of the people, barely alive, dropped.

Many were there, wrapping his brother's wounds,

instantly making room for him, exalted,

while they were conquering the mighty killing field.

183 Alexandra Reider (1l. 2956-2970)

184 George Ferzoco (1l. 2971-2985) 
READER'S NOTES AND TRANSLATION 
Then ${ }^{185}$ one warrior plundered the other.

He took from Ongenthio an iron mail-coat,

A hard, hilted sword, and his helmet, too.

To Hygelac he carried the armor of the frost-haired one;

He accepted those trappings, and fairly promised him

Rewards among the people, and made it so.

The prince of the Geats paid for the battle-rush,

The son of Hrethel, when he came to his home,

With an excess of treasure for Iofor and for Wulf.

He gave to each of them a hundred thousand things,

Lands and interlocked rings: none needed

To impeach that payment, no man on middle-earth,

After they struck down the greater, more famous man.

And then he gave to Iofor his own daughter,

As a grace for his home, with honor as a pledge.

Now ${ }^{186}$ that is the fright and that is the foe-hood

3001

mortal threat to men, mighty hatred,

that forsooth I expect from Swedish people

once the wind they get of our warlord's drawing

his final breath, he who barred for years

the treacherous enemies from treasure and land,

his retainers might fall, but unflinchingly the warrior

to his country tended, a true leader of men,

beyond measure. Now we better make haste

and do your duty, behold our dear king

and help him onwards, the offerer of ringlets,

onto the funeral pyre. Not a fraction meagre

shall melt with the mighty one, but that whole mound there,

ill-begotten, of gold beyond count,

for its price is loathsome- his life itself it was

as bought the bracelets. Thus to burn is their fate,

to be charred by fire; no champion shall have

any treasure to toy with, no trinkets shining,

nor a maiden her neck with necklace adorn,

for we shall all in despair, dispossessed of gold,

not once, but many times be exiled from homeland,

now that the lord of battle is of laughter bereft,

is starved of merriment. Now steely spears

on chilly mornings champions numerous

in hands will clasp, for no harp's sounds

185 Thomas A Bredehoft (1l. 2986-3000)

186 Ilya V Sverdlov (ll. 3001-3030) 
READER'S NOTES AND TRANSLATION 
will warriors wake, but woeful raven's

clamorous cackle, as clawing the dead

to the falcon he boasts of feasting gloriously

on yet writhing bodies, with wolf for company!"

These were the words of the warrior valiant,

of ${ }^{187}$ dreadful tidings. He did not lie at all

3031

in deeds or words. The warband all rose,

went grieving under Earnanæs

with scalding tears to see the wonder.

There on the sand they found, soulless,

holding his rest-bed, the one who gave them rings

in earlier times. Then had the end-day

come for that good man, the war-king,

Prince of the Wederas; he died an awesome death.

But first they had seen a rarer creature,

dragon on the plain, lying opposite there,

dreadful. It was the firedragon,

grim horrorguest, burnt by flames.

He was fifty foot-measures

Long as he lay. In air-joy he had ruled

at ${ }^{188}$ night-time, and afterwards went down

to seek his den. Then he was fixed in death,

he had made his last use of earth-caves.

Goblets and cups stood beside him,

dishes and precious swords lay,

rusted, eaten-through, as though they had remained there

for a thousand winters, in the earth's embrace.

Indeed, that mighty legacy,

the gold of ancient men, was surrounded by a spell,

so that no man could reach the ring-cave

unless God himself,

the true king of victories, permitted him whom He wished-

He is the protector of men-to open the hoard,

even to such men as seemed fitting to Him.

187 Erin Sebo (1l. 3031-3045)

188 Harvard University, English 103G: "Beowulf and its Contexts" Class: Joey McMullen, Patrick McCoy, Deirdre Carney, Lauren Claus, Jack Goldfisher, Daniel Hellstrom, Lauren Herring, Natalie Hodges, Emma Kantor, Anna Kelner, Brittany Ledford, Joan Li, Emily Ott, Dylan Perese, Michael Savarese, Joseph Shack, and Erik Tamre (ll. 3046-3075) 
READER'S NOTES AND TRANSLATION 


\section{XLII}

Then it was evident that the undertaking was not profitable for the one who wrongfully hid his misery within, under the wall. The guardian earlier slew an extraordinary man. Then the feud was cruelly avenged. It is a wonder then, where a brave nobleman may reach the end of his fated life, when he can no longer, a man among his kinsmen, inhabit the mead-hall.

So it was for Beowulf, when he sought out the barrow's guardian, his cunning hostilities. He himself did not know how his parting from the world should come about. Thus the great lords, who placed the treasure there, solemnly declared it so until doomsday, that a man would be guilty of crimes, imprisoned in pagan shrines, fixed in hell-bonds, punished with misfortunes, should he plunder that place. $\mathrm{He}^{189}$ who had earlier beheld

the owner's mercy was not gold-greedy.

Wihstan's son Wiglaf spoke.

"Often many men will come to grief by one man's will, as has happened to us. No counsel could persuade the beloved prince, the kingdom's keeper, that he should not attack the gold-guardian but let him lie where he long had been, occupying his dwellings until world's end. He seized his high destiny. The hoard has been seen, won with pain. That fate which drove him here was too powerful.

I was in there and when a way was cleared for me, studied all the hall's treasuresthe path in beneath the earth wall was not at all easily won.

$$
\operatorname{In}^{190} \text { haste I seized }
$$

with my hands a great and mighty burden

of hoard-treasures, bore it out here

to my king. He was still alive then, wise and conscious: a great many things spoke that ancient one in sorrow, and commanded you to be greeted,

189 Hilary E. Fox (1l. 3076-3092a)

190 David Clark (ll. 3092b-3105) 
READER'S NOTES AND TRANSLATION 
bade that, in accordance with our friend's deeds, you make the high barrow on the pyre-place great and glorious-since he was of men the most worthy of warriors widely throughout the earth while he was able to enjoy the fortress-wealth.

Let us now hasten a second time to see and seek the heap of precious gems, wonders under the wall-I will guide you, so ${ }^{191}$ that you may see nearby plenty of rings and gold galore. Let the bier be ready, quickly prepared, when we come out, and then we may lead our lord, the beloved man, where he must long remain in the Creator's care."

Then the son of Wihstan ordered an announcement, the battle-hardened hero, to many of the warriors, the hall-rulers, that they, the people's leaders, should carry the pyre-wood from afar to the good man. "Now must the fire, the dim flame growing, feed on the chief of warriors, who often endured the hail of iron points when the storm of arrows, flung with force, shot over the shieldwall. The shaft did its duty, hastening in its feather-gear, aided by its arrow-head." But ${ }^{192}$ Weohstán's wise son,

Called forth from the troop of king's thegns, Seven together, the best.

They went, eight in all, under the hostile roof One of the warriors, he who walked in front, Bore shining fire in his hand.

Nor were lots drawn for any part of that hoard, By those who plundered it, now unguarded and useless as men saw it, lying in the hall.

Little any mourned that they hastily carried out the costly treasures. The dragon also they discarded, the worm over the cliff wall, letting the wave, the flood's embrace, take the guardian of precious things. 
READER'S NOTES AND TRANSLATION 
Twisted ${ }^{193}$ gold, the never-ending treasure, they loaded on the cart carrying the prince, the grey-haired hero, to Whale's Headland.

\section{XLIII}

For him, for him the Geats make ready a pyre upon the earth, a splendid one. Helmets hang round it, shields battle-worn, shiny mail-coats - just as he wanted. Grieving warriors lay among them the famous prince, their hero, their beloved lord. They light it up, the biggest of pyres right there on the mound; the wood-smoke rises in dark billows. The wind-it stops.

The crashing ardour of the flame mingles with their lament until it breaks his body, burns the heart.

With ${ }^{194}$ sad hearts

they mourned their sorrow of spirit, the death of their lord.

A Geatish woman also sang a song of mourning, with bound-up hair, she was not lighthearted; sorrowful, she earnestly said that she sorely dreaded their invasions, the great number of slaughters, the troop's terror, the humiliation and captivity. Heaven swallowed the smoke.

The people of the Weders then constructed a mound on the headland; it was high and broad, widely visible to seafarers, and they built in ten days the monument of the battle-bold one on the leavings of the fire. They constructed a wall, as worthily as very wise men could devise it. They placed rings and brooches in the barrow, 
READER'S NOTES AND TRANSLATION 
all $^{195}$ such treasures as hostile men had earlier taken away from the hoard.

They let the earth hold the wealth of earls, gold in the sand, where it still lives now; as useless to men as it was before.

Then the battle-brave sons of nobles rode around the barrow, twelve in all.

They wished to lament their sorrow and speak of their king, to recite an elegy and commemorate that man.

They praised his nobility and his brave deeds that the troop valued, as it is fitting that a man should praise his lord with words, honor him in his memory, when he must be brought forth from his earthly body. Thus the Geatish people, his hearth-companions, mourned their lord's death.

They said that he was a king in the world mildest of men, and most loyal;

kindest to his people, and most eager for glory. 